\author{
JAMES L. PIERCE \\ Staff, Board of Governors \\ of the Federal Reserve System \\ and
}

JARED J. ENZLER

Staff, Board of Governors

of the Federal Reserve System

\title{
The Effects of External Inflationary Shocks
}

THE ECONOMY IS ALWAYS VULNERABLE to a variety of external influences or shocks that have important impacts on income, employment, and prices. While these external shocks are unforeseeable and unavoidable, economic policy must somehow deal with their consequences.

Lately an alarming number of upward jolts to prices have come from sources beyond the normal interaction of production, wages, and prices. One was the relative decline in the value of the dollar following the abandonment of the system of fixed exchange rates, which raised the prices of imported goods and contributed to the rise in farm prices as exports competed with domestic consumption. A number of other events shook the economy at about the same time. Crop failures in the Soviet Union resulted in a gigantic sale of American grain. The Peruvian anchovy catch mysteriously

Note: The views expressed in this paper are our own and do not necessarily reflect those of the Federal Reserve Board or its staff. We want to thank members of the Brookings panel for their many constructive comments on an earlier version of this paper. 
dropped, contributing to a worldwide protein shortage and higher prices for feedstocks. Then floods in the Midwest destroyed part of the soybean crop, driving feedstock prices still higher. Late in 1973, a cartel of oil producers got the upper hand over the buyer cartel and forced fuel prices drastically upward. Finally, the dismantling of domestic price controls may undo whatever downward pressures the program had on the price level. Because these inflationary surges have substantial effects on real income and on relative prices, their implications for economic stabilization policy deserve examination.

The consequences of the recent upward shocks to prices will be analyzed under the assumption that they are permanent, even though they may be overshadowed by downward disturbances from other sources, or even partly reverse themselves (anchovies may reappear off the coast of Peru and soybean fields may yield a bumper crop, for example). This assumption permits analysis of the longer-run consequences of external disturbances that are not quickly reversed.

Table 1 presents recent growth rates of selected price deflators from the national income accounts. Farm and import prices have risen at a tremendous rate; many of these increases have found their way into consumer prices, which have risen substantially relative to the nonfarm business deflator. The extent to which monetary policy has contributed to the current high rates of inflation is a subject of considerable controversy. We will not enter into this debate, but rather will deal with the impact of external infla-

Table 1. Changes from Preceding Quarter in Selected Price Deflators, National Income Accounts Basis, 1972 and 1973

Seasonally adjusted annual rate of change in percent

\begin{tabular}{rccccc}
\hline $\begin{array}{c}\text { Year and } \\
\text { quarter }\end{array}$ & $\begin{array}{c}\text { Gross } \\
\text { national } \\
\text { product }\end{array}$ & $\begin{array}{c}\text { Consumer } \\
\text { nondurables } \\
\text { and services }\end{array}$ & $\begin{array}{c}\text { Nonfarm } \\
\text { business, } \\
\text { adjusted }^{\mathrm{a}}\end{array}$ & $\begin{array}{c}\text { Farm } \\
\text { business }\end{array}$ & Imports \\
\hline $1972: 1$ & 5.7 & 3.0 & 5.0 & 20.6 & 3.8 \\
2 & 1.6 & 2.9 & 0.8 & 19.2 & 15.4 \\
3 & 2.7 & 3.2 & 1.8 & 28.7 & 6.7 \\
4 & 3.3 & 4.3 & 2.8 & 23.2 & 7.9 \\
$1973: 1$ & 6.0 & 6.9 & 4.3 & 50.5 & 12.1 \\
2 & 7.2 & 8.7 & 5.4 & 75.8 & 40.9 \\
3 & 7.0 & 7.2 & 5.0 & 107.4 & 20.0 \\
4 & 8.7 & 10.0 & 7.1 & 4.2 & 35.6 \\
\hline
\end{tabular}

Source: Official data from the U.S. Bureau of Economic Analysis.

a. Nonfarm business price deflator adjusted for federal indirect business taxes. 
tionary shocks to the economy and with the special problems that these disturbances pose for monetary policy. ${ }^{1}$

An important issue for monetary policy is the type of response that is appropriate to externally induced surges in inflation. Some observers have argued that monetary policy should respond vigorously to these price surges, while others believe that policy should "accommodate" them, at least in the short run. This paper argues that the concept of accommodation is a slippery one in this context. Furthermore, the effects of price disturbances may depend in part on the source of the shock, and so, therefore, may the appropriate response of monetary policy.

To examine these matters, we have used a modified version of the MPS (MIT-Penn-SSRC) quarterly econometric model to obtain quantitative estimates of the effects on individual sectors and on the economy as a whole of imposing domestic price controls and of a rise in foreign oil prices. The model has been adjusted and modified in ways described below to make it a more suitable tool for analyzing the special problems under study.

The following section attempts to assess the initial impact of external inflationary shocks on individual sectors of the economy considered in isolation. The sectors most relevant for the analysis include the money market, consumption expenditures, and the interaction of wages and prices. The next section reports a simulation of the full model to study the effects of these shocks on the economy as a whole, and concludes with a discussion of the possible implications for monetary policy.

\section{Initial Impacts of Shocks}

In this section, we start with a general, qualitative, discussion of the initial impacts of the shocks on each sector, and then turn to a more detailed discussion of these impacts on the relevant sectors of the MPS model.

\section{A BRIEF OVERVIEW}

First we consider the impact that a sharp increase in the price of an imported commodity - in this case, oil-has on the demand for money.

1. While fiscal policy can, and probably should, play an important role in combating the effects of external shocks, this paper will deal only with monetary policy. 
In keeping with accepted doctrine, we shall assume that the public's demand for money varies directly with the volume of transactions and inversely with market interest rates. ${ }^{2}$ But this discussion calls attention to the wellknown problems of an appropriate measure of transactions.

Gross national product, which is often used as a proxy for transactions, ignores such potential complications as the level of integration of the economy and the absolute levels of imports and exports. Thus, for example, if import prices rise relative to other prices, the GNP deflator will remain unchanged. The rise in the prices of consumption and investment goods containing imports will be offset by the corresponding rise in prices of imports themselves. Thus, both nominal and real GNP remain unchanged. However, importers and purchasers of final consumption and investment goods will wish to hold larger money balances at given interest rates and nominal GNP to support the larger value of their transactions. Thus, when import prices rise, the corresponding rise in transactions-and hence money demand-are missed if GNP is used as the measure of transactions.

If the prices of exports rise relative to other prices, the GNP deflator and nominal GNP will both rise. The demand for money should rise with GNP, but probably less than when domestic prices rise; domestic purchasers of final investment and consumption goods feel no need to hold larger money balances because the value of their transactions has not risen.

In analyzing the increase in oil prices, we will use GNP plus imports as our measure of transactions demand, and will provide evidence on the importance of this arbitrary adjustment. While this measure probably overstates the impact on transactions of an increase in prices of imported oil, it sets an upper limit to that effect. Because we do not consider export prices, no adjustments need be made to the transactions variable for this factor.

The initial effects on the monetary sector of an increase in the prices of imported oil follow from this discussion of transactions demand. Assume that the volume of real transactions is unchanged, at least initially, by a rise in import prices (or, more realistically, that any initial drop in real transactions is small relative to the price increase). The nominal value of transactions (GNP plus imports) increases, as just described, augmenting

2. For an excellent discussion of money demand functions, see Stephen M. Goldfeld, "The Demand for Money Revisited," Brookings Papers on Economic Activity (3:1973), pp. 577-638. Hereafter this document will be referred to as $B P E A$, followed by the date. 
the demand for money at given interest rates and GNP. Thus, other things equal, interest rates will rise if the money stock is fixed.

The analysis of the initial impact of the increase in the price of imported oil on the real volume of consumption expenditures is straightforward. Although higher import prices do not raise the GNP deflator they do raise the prices of consumption goods. This rise reduces the real value of disposable income and of household net worth, since the nominal values of these variables are unaffected. Thus, initially the price increase will reduce real consumption expenditures. Nominal consumption expenditures are likely to rise at first because consumers will adjust real purchases slowly to their reduced real incomes and net worth. Thus, nominal saving drops initially.

The direction, if not the size, of the initial impact on wages and prices also can be anticipated. The surge in import prices will make the goods that workers buy more expensive, putting pressure on wages, and in turn tending to raise domestic prices.

The prices of import-competing goods should also respond. An increase in the world price of an internationally traded commodity like oil would, in the absence of regulation, probably spur the same increase in the domestic price. Prices of energy substitutes, such as coal, should rise as demand shifts from oil. Domestic energy producers may find it profitable to export their product, thus further bidding up the oil prices.

These increases in domestic prices will reinforce the impacts of new prices of imports. In particular, the transactions demand for money will expand (this time because nominal GNP rises), putting additional upward pressure on interest rates; real consumption expenditures will drop further due to the additional decline in real disposable income and wealth; finally, wages and prices will tend to rise in response to the increase in domestic prices.

A rise in domestic oil prices will not be as deflationary as a rise in import prices of equal size because corporate profits and investment will be greater, and the stock market will not experience as serious a decline as results when profits go to foreigners. Because of these differences, the effects of a rise in domestic oil prices are qualitatively more like those of decontrolling domestic prices when they are under pressure to rise- the second economic event considered in this paper.

\section{RELEVANT SECTORS OF THE MPS MODEL}

The impacts described above can be given somewhat greater precision by analyzing them in terms of the sectors of the MPS model. The demand 
equation for the public's holdings of demand deposits, as modified by the addition of imports, is shown in equation (1):

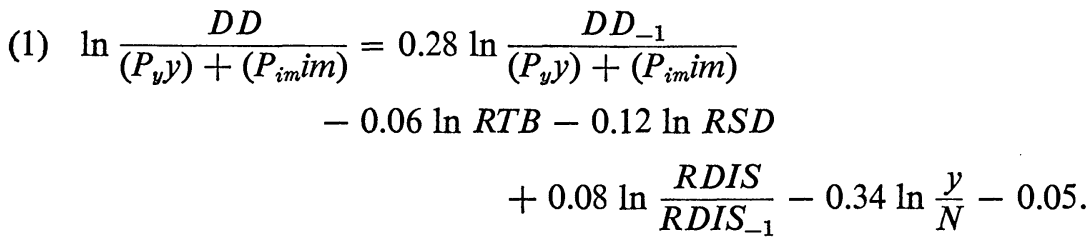

The demand for nominal demand deposit balances $(D D)$ varies directly with real GNP $(y)$, real imports $(i m)$, the GNP and import deflators $\left(P_{y}\right.$ and $\left.\mathrm{P}_{i m}\right)$, changes in the Federal Reserve discount rate $(R D I S)$, and population $(N)$. The demand varies negatively with the Treasury bill rate $(R T B)$ and the savings deposit rate $(R S D)$.

The basic notion in this formulation is that firms and households desire demand deposit balances for transactions purposes. In equation (1), changes in the prices of both domestically produced and imported goods have a powerful impact on money demand. ${ }^{3} \mathrm{~A} 1$ percent rise in a weighted average of domestic and import prices produces a 0.72 percent rise in deposit demand in that quarter and a 1 percent rise in the long run. Thus, during recent periods when import prices have risen by as much as 10 percent in a quarter, the demand for money has increased significantly. ${ }^{4}$ For a given money stock these surges in money demand exert upward pressure on interest rates.

The consumption function in the model is

$$
\frac{c o n}{N}=\sum_{i=0}^{11} b_{i} \frac{Y_{d}}{N_{-i}}+\sum_{i=0}^{7} d_{i} \frac{V C W}{P_{c o n} N_{-i}}+0.054 \frac{V O W}{P_{c o n} N},
$$

where

$$
b_{0}=0.10, \sum_{i} b_{i}=0.66 ; \text { and } d_{0}=0.016, \sum_{i} d_{i}=0.054
$$

Real per capita consumption $(\operatorname{con} / N)$ depends on a distributed lag on real

3. A similar adjustment for imports is not necessary for the currency equation because it uses the value of consumer expenditures, which include import prices, as the transactions variable. The currency equation is not shown because, except for this difference, it is basically of the same form as the demand deposits equation.

4. A 10 percent increase in the price of imports would raise the value of GNP plus imports by about 1 percent. Thus, given interest rates, deposit demand will rise by 1 percent in the long run. Currency demand also has a unitary elasticity with respect to prices in the long run, but it is based on personal consumption expenditures, which constitute about two-thirds of GNP. Thus, currency demand will rise by 1.5 percent in this case. 
per capita disposable income $\left(Y_{d} / N\right)$, a distributed lag on the common stock portion $(V C W)$ of real per capita consumer net worth, and the value of the remaining portion of net worth $(\mathrm{VOW})$ at the beginning of the quarter. The coefficients indicate that a rise in the price of consumption goods $\left(P_{c o n}\right)$ will have a sizable effect on real consumption through the reduction in real disposable income and real net worth. The very short lag for VOW is troublesome and its implications will be analyzed below.

Wage-price interactions are a key vehicle through which external inflationary shocks are transmitted to the economy. We shall discuss the wageprice sector in considerable detail because we have reestimated the wage equation, and its properties are rather different from those in the conventional MPS model. ${ }^{5}$ We shall also attempt to isolate those variables in the wage-price sector that will be most important for the outcome of the fulleconomy simulations that follow.

\section{THE WAGE EQUATION}

The wage equation is a modified Phillips curve in which the percentage changes of wages $(P L)$, measured by compensation per manhour in nonfarm private domestic business, varies inversely with the unemployment rate $(U L)$ and directly with the percentage change in consumption goods prices $\left(P_{c o n}\right)$, the level of social security and unemployment taxes $(S S)$, and the percentage change of the minimum wage $\left(P_{m i n}\right)$. The estimated equation is

$$
\begin{aligned}
\frac{\Delta P L}{P L_{-1}} & =0.031 \frac{1}{U L}-0.017 \frac{\Delta U L}{U L_{-1}}+0.004 S S+0.009 \frac{\Delta P_{\min }}{P_{\text {min }}} \\
& +0.99\left[\frac{1}{\sum_{1}^{12} 0.87^{i}} \cdot \sum_{1}^{12} 0.87^{i} \frac{\Delta P_{c o n}}{P_{c o n}-i-1}\right]-0.007 D-0.00005
\end{aligned}
$$

where wage increases are measured as percentage annual rates and $D$ is a dummy variable to capture the wage freeze in 1971:4 and wage release in 1972:1.

The initial impact of the increase in the price of consumption goods $\left(P_{c o n}\right)$ on the growth of wages is small but in the long run consumer prices will rise almost proportionately to wages, given the unemployment rate.

5. George de Menil and Jared J. Enzler, "Prices and Wages in the FRB-MIT-Penn Econometric Model," in Otto Eckstein (ed.), The Econometrics of Price Determination (Board of Governors of the Federal Reserve System, 1970). 
Thus, the wage equation used in this study does not allow a significant tradeoff in the long run between inflation and the unemployment rate. Because the long-run coefficient on the rate of change of prices is essentially unity, attempts to reduce unemployment below its "natural" rate ultimately will fuel an explosive increase in the rate of inflation. This property, and some others that will be discussed below, calls for a justification of this wage equation.

In the light of recent work by such researchers as Robert Gordon and George Perry, ${ }^{6}$ our equation may seem to lag the current state of the art. Working within the context of a large econometric model, however, poses problems for the construction of a single sector. Thus, explanatory variables endogenous to the economic system cannot be employed unless equations for those variables can be produced. For this reason the fixed-weight unemployment rate by age and sex that Perry uses as the labor market variable is difficult to incorporate. We encounter similar difficulties with Gordon's formulation of the dependent variable in the wage equation as a series on hourly earnings corrected for changes in overtime and interindustry employment shifts.

Equally important is the need to strike a compromise between the ability to explain an individual sector and the ability to track the entire system. Although most equations in the MPS model are estimated by single-equation methods, the best-fitting form of an estimated equation clearly is not always the ultimate best choice. The effects that various alternative estimates of a particular equation have on the tracking properties of the model and on its responses to various kinds of shocks are important criteria. These properties can be tested only by simulation.

One of the most vexing questions in this regard is the size of the long-run coefficient on the price term in the wage equation. Until recently the bestfitting equations of the type presented here had estimated long-run coefficients substantially less than unity. According to these equations, a considerable tradeoff between unemployment and inflation was possible even in the long run. Once the 1969-71 experience is added to the sample period, however, the estimated price coefficient usually increases markedly to about unity. Furthermore, the average lag for the price term in most of these equations is remarkably short.

Gordon has demonstrated that the wage equations using the concepts

6. George L. Perry, "Changing Labor Markets and Inflation," BPEA (3:1970), pp. 411-41; Robert J. Gordon, "Wage-Price Controls and the Shifting Phillips Curve," BPEA (2:1972), pp. 385-421. 
developed by Perry, noted above, do not yield a high long-run coefficient for price change even when estimated through $1970 .{ }^{7}$ In the course of estimation, we tried to approximate the effect of Perry's hypothesis concerning composition of the unemployment rate by adding to the wage equation a number of variables designed to capture this effect. The proportion of teenagers in the adult population was tested and consistently yielded the wrong sign. The proportion of persons aged 20-24 years had the correct sign but was statistically insignificant, and the coefficient was so small that this variable could account for only negligible shifts in the Phillips curve. We tried entering children under 5 years as a percent of the adult population, on the theory that when the birth rate is high, female participation rates are low and a given unemployment rate should put greater downward pressure on wage changes. This variable consistently had the right sign but was very weak. Most important, none of these variables, either alone or in combination, had a noticeable effect on the price coefficient. We were unable to estimate a wage equation with a long-run coefficeint below 0.8 .

We also tried Gordon's suggestion of a flexible price coefficient that depends on the rate of inflation. ${ }^{8}$ We attempted to estimate equations with two price variables, a short distributed lag on the total rate of increase in consumer prices and a longer distributed lag on the excess of inflation above some threshold. This formulation introduced a kink in the long-run Phillips curve. When the threshold was high, the sum of the price coefficients always exceeded 0.8 and the threshold variable itself was not significant. When the threshold was lowered, the threshold variable became significant and the sum of the coefficients rose to approximately unity. Although this specification worked well in estimation, the full model proved to be highly unstable when simulated with this sort of equation. When the long-run coefficient on prices is near unity and when the lag on prices is short, errors in other equations quickly cumulate to large errors in wages and prices. ${ }^{9}$ We then experimented with forcing longer price lags into the wage equation and finally settled on equation (3), which uses a single exponential lag based on 0.87 ; that is, roughly 16 percent-

$$
100\left(\frac{0.87}{\sum_{1}^{12} 0.87^{i}}\right)
$$

7. Ibid.

8. Ibid.

9. This unstable process will occur before the higher prices can force up interest rates and unemployment sufficiently to correct the original disturbance. 
-of an increase in $P_{c o n}$ in the previous quarter is translated into a wage increase in the current quarter and the weights decline exponentially thereafter as powers of 0.87 . It was possible to introduce the longer lag with a modest loss in fit. The best-fitting equation we estimated has a standard error of about 1.3 percent per quarter at annual rates compared to 1.4 in equation (3). These errors are only slightly larger than those found in other studies despite the fact that the equation uses the relatively erratic series on compensation per manhour. The average lag implied by the 0.87 coefficient is 4.9 quarters.

This modification produced a wage equation that seemed more in accordance with our observations on the dynamics of wage determination. We were also comforted by the improvement in the full-model simulations when this equation was used, in the sense that the results accorded better with our a priori expectations concerning the reaction of the economy to shocks. The longer lag on prices gives the system time to react and to correct any errors in simulated prices. Not surprisingly, as the length of the price lag is extended, the size of the coefficient on the inverse of unemployment is increased. In the estimated equations using short price lags, the unemployment coefficient is about one-half of that reported in equation (3). Thus, the size of the coefficient and the length of the price lag have offsetting effects and the reaction of the wage-price system to changes in the unemployment rate is not very different when the length of the lag on the price term is altered. Lengthening the lag strengthens the initial impact of a given change of the unemployment rate on the rate of wage increases, but wages will react more slowly to the price increase. Lengthening the lag does moderate the volatility of the wage-price system in response to other influences, such as an increase in unfilled orders or productivity. Thus, the longer lag form makes the full model more stable.

This discussion emphasizes the uncertainties inherent in modeling the wage process. The structure of the wage equation is obviously important to the question we are addressing. Yet a considerable number of hypotheses about the structure of the wage-price sector fit the facts about equally well, but carry different implications for the impact of changes in the full model of the economy. This is obviously a source of concern.

Figure 1 shows dynamic simulations of the percentage changes of wages using actual values of the explanatory variables, including prices, in the wage equation. A four-quarter annual percentage change, $100\left(P L_{t}-P L_{t-4}\right)$ / $\left(P L_{t-4}\right)$, was constructed in order to smooth out fluctuations in the actual 


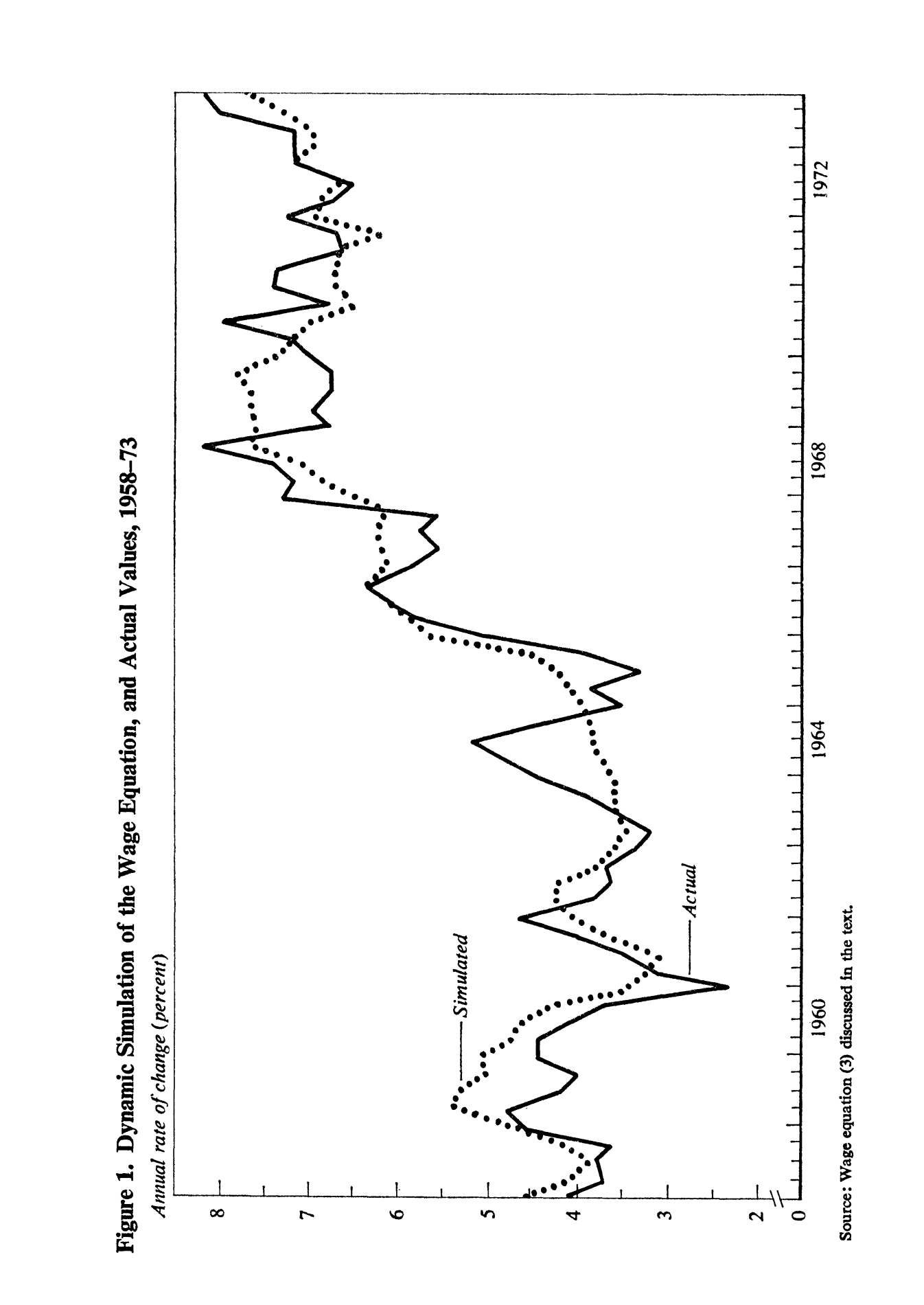


data that would make the chart difficult to read. The wage equation performs quite well over the period, but, surprisingly, shows little or no effect of the wage-price control program once the slowdown in prices is allowed for, as it is in this simulation. This finding suggests that the only influence controls had on wages was the indirect if powerful one asserted through the downward pressure on prices. ${ }^{10}$ This finding is not simply the result of estimating the wage equation over the period that included the price control episode. In the simulations of dozens of different wage equations, either using dummy variables for the control period or ending the sample period in 1971:2, we have never found any evidence of a direct effect on wages other than in the freeze quarter 1971:4.

\section{THE PRICE EQUATION}

The price equation in the model is

(4) $\ln P_{n f}=0.2901 \ln P L+0.073 \frac{U O P D}{E P D}-0.040 \frac{U O P D_{-1}}{E P D_{-1}}$

$$
\begin{aligned}
-0.001 T I M E-0.0075 & \sum_{i=0}^{7} \ln \frac{y_{n f}}{M H_{-i}} \\
& -0.013 \ln \frac{P_{r m}}{P_{r m_{-1}}}+0.710 \ln P_{n f_{-1}} .
\end{aligned}
$$

The equation can be viewed as expressing prices (private nonfarm deflator net of excise taxes, $\left.P_{n f}\right)$ as a markup over labor costs $(P L) .{ }^{11}$ The markup varies positively with the ratio of unfilled orders of producers' durables to shipments ( $U O P D / E P D)$, which serves as a measure of capacity utilization; negatively with a productivity time trend; and negatively (but weakly) with cyclical variation in output per manhour $\left(y_{n f} / M H\right)$ around its trend. The markup also varies negatively with the change in raw material prices $\left(P_{r m}\right)$ as an impact variable. The nonfarm business sector now accounts for 85 to 90 percent of real GNP. Government is excluded because the "price" of government is really a wage, and farm output is excluded because it is subject to forces, such as weather, that we cannot explain in economic terms.

10. For a similar result, see Robert J. Gordon, "The Response of Wages and Prices to the First Two Years of Controls," BPEA (3:1973), pp. 765-78.

11. Since it determines the relationship between prices and wages and since labor requirements are determined elsewhere in the model, the equation also determines the profit share. 
The nonfarm deflator is a value-added deflator; that is, it is calculated as a weighted average of the prices of business output less a weighted average of the prices of the raw materials businesses buy. For the business sector as a whole, the raw material inputs consist mainly of imports and farm products. If prices of these raw materials increases, and the cost is not passed along to final consumers, the nonfarm business deflator actually falls. Because of this phenomenon, changes in raw materials prices $\left(P_{r m}\right)$ enter the deflator equation with a negative sign. This term has only a transitory effect, however, as these changes are eventually passed on to consumers. Finally, the equation has a lagged dependent variable with a coefficient indicating that if any of the determinants of the price level change, about 30 percent of the complete price adjustment is made in one quarter.

Figure 2 shows a dynamic simulation of the price equation using actual values of the right-hand variables, except for the lagged dependent variable which takes on the predicted value from the previous quarter. The equation performs quite well until 1971:3, when it begins to simulate prices too high, which suggests that the price control program has had a dampening effect on the price level. It should be stressed that the simulation does not capture the full effect of the price controls on the price level. We argue below that if price controls had not been imposed, the higher prices that would have ensued would have led to higher wages and then to even higher prices. This interaction of wages and prices considerably enlarges the effect of controls that appears in Figure 2.

Closing the wage-price sector calls for three identities:

$$
\begin{gathered}
P_{c n d}=U_{c n d} P_{n f} \\
P_{c d}=U_{c d} P_{n f} \\
P_{c o n}=\frac{c_{n d} P_{c n d}+0.01 P_{c d}\left(W C D+0.01 R C B . K_{c d}\right)}{c_{n d}+\left(W C D+0.0379 K_{c d}\right)} .
\end{gathered}
$$

Equation (5) relates the deflator for consumer nondurables and services $\left(P_{c n d}\right)$ to the nonfarm business deflator by the ratio $U_{c n d}$. Equation (6) does the same for the consumer durable deflator $\left(P_{c d}\right)$ using the ratio $U_{c d}$. Actual historical values for these ratios were used in each quarter. We do not attempt to explain these ratios, since they depend in large part on three items for which behavioral equations are difficult to construct: the price of imported goods, the price of farm products, and the federal excise tax rate.

The consumption price deflator $\left(P_{c o n}\right)$ is defined as a weighted average of the price of nondurables and the price of the services of durables. It is 


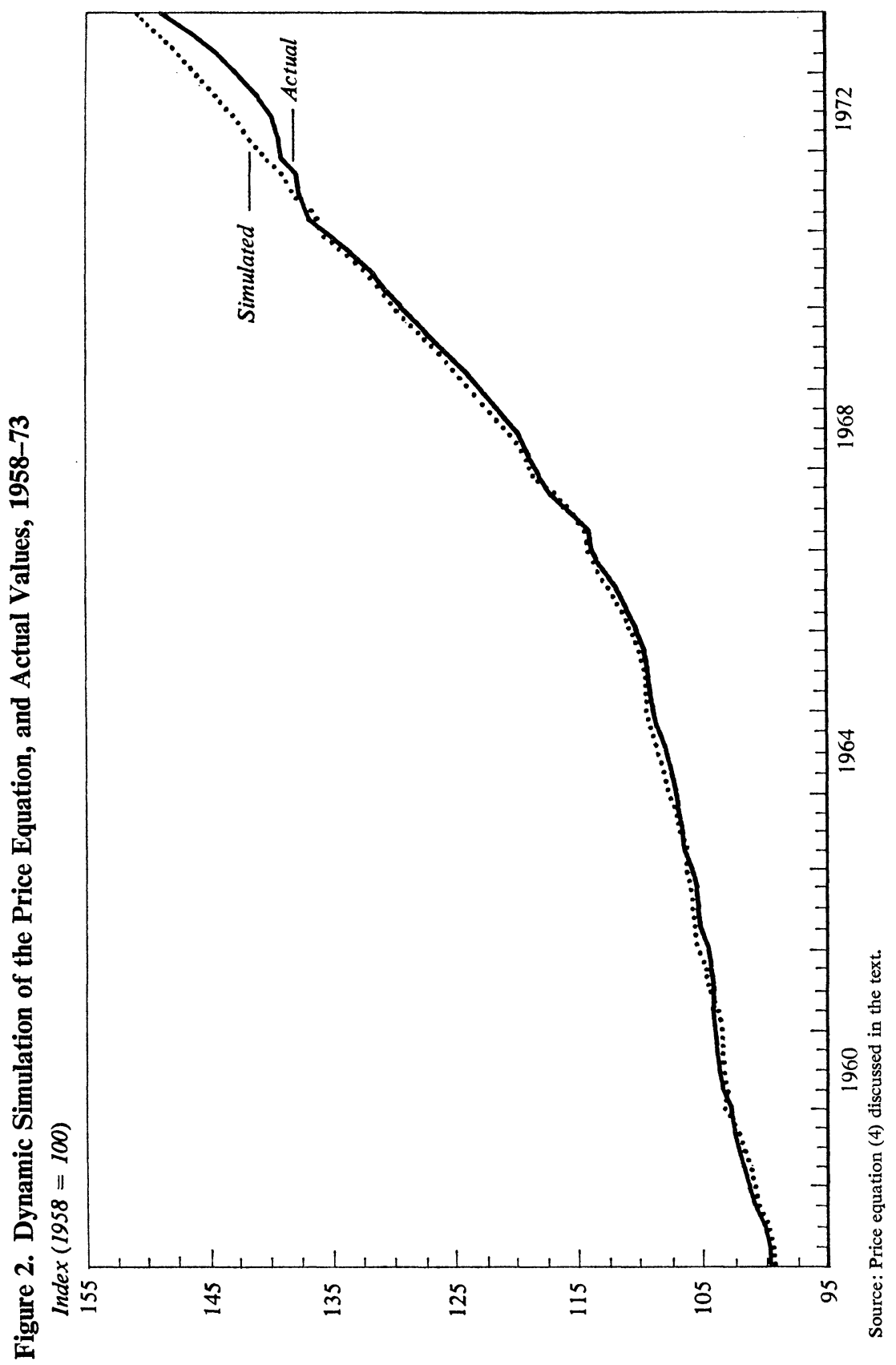


determined in equation (7) as the ratio of the sum of (1) current-dollar purchases of consumer nondurables and services $\left(c_{n d} P_{c n d}\right)$ and (2) currentdollar consumption of the services of the stock of durable goods, to the sum of $c_{n d}$ and the consumption (in 1958 dollars) of the services of the stock of durable goods. The term $P_{c d}\left(W C D+0.01 R C B \cdot K_{c d}\right)$ measures the imputed rental services from durable goods in current dollars, where $W C D$ is the depreciation on consumer durables and $K_{c d}$ is the stock of consumer durables, both in 1958 dollars, and $R C B$ is the current interest rate on corporate bonds. The expression $\left(W C D+0.0379 K_{c d}\right)$ measures the imputed services from durables in 1958 dollars, where 0.0379 is the average value of $R C B$ in 1958.

\section{INTERACTION OF WAGES AND PRICES}

How does the wage-price sector, considered in isolation from the rest of the full model, respond to an increase in consumption prices? Wages will rise in response to this shock, and spur a further increase in prices. But if unemployment is unchanged and if the long-run price coefficient in the wage equation is less than unity, these feedbacks will not accumulate indefinitely. In this case, the rate of price increase will eventually return to what it would have been in the absence of the shock, although the level of prices will be higher. If, however, the long-run coefficient is unity, this feedback mechanism will continue without end, and the rate of inflation will be permanently higher, but by only a limited amount even in this case. For inflation to increase without limit requires a permanent reduction in the unemployment rate.

In order to study the adjustment of the wage-price sector in response to an external price shock, we did two simulations of the sector for the sevenyear period 1967 through 1973. In the first, the sector was simulated as is. In the second, the ratio of the consumer nondurable deflator to the nonfarm business deflator ( $U_{c n d}$ of equation 5) was increased by 1 percent in the first quarter of the simulation (raising $P_{c o n}$ by an annual rate of 3.44 percent that quarter) and held at the new higher level to capture the effect of a permanent rise in the price level of a commodity like imported oil. The effects of this permanent increase in $U_{c n d}$ on the rate of change of wages, the nonfarm deflator, and $P_{c o n}$ are measured by the difference between the two simulations, and are reported in Table 2.

The deflator for consumer nondurables and services $\left(P_{c o n}\right)$ increases at a 
Table 2. Simulated Effect on the Wage-Price Sector of a

Rise in Consumption Prices, by Selected Quarters

Deviation from control simulation in annual percent rate of change

\begin{tabular}{cccc}
\hline $\begin{array}{c}\text { Quarter of } \\
\text { simulation }\end{array}$ & $\begin{array}{c}\text { Compensation } \\
\text { per manhour }\end{array}$ & $\begin{array}{c}\text { Private nonfarm } \\
\text { deflator net of } \\
\text { excise taxes } \\
\boldsymbol{P}_{n f}\end{array}$ & $\begin{array}{c}\text { Consumption price } \\
\text { deflator } \\
\boldsymbol{P}_{\text {con }}\end{array}$ \\
\hline 1 & 0.00 & 0.00 & 3.44 \\
2 & 0.54 & 0.16 & 0.15 \\
3 & 0.50 & 0.26 & 0.24 \\
4 & 0.47 & 0.32 & 0.30 \\
5 & 0.45 & 0.36 & 0.36 \\
6 & 0.46 & 0.38 & 0.38 \\
7 & 0.46 & 0.40 & 0.41 \\
8 & 0.46 & 0.42 & 0.41 \\
12 & 0.49 & 0.46 & 0.46 \\
16 & 0.42 & 0.44 & 0.43 \\
20 & 0.43 & 0.43 & 0.44 \\
24 & 0.42 & 0.42 & 0.43 \\
28 & 0.41 & 0.41 & 0.42 \\
\hline
\end{tabular}

Source: Simulations in which the ratio of the consumer nondurable deflator to the nonfarm business deflator is held 1 percent above historical values in each quarter of the simulations. See text for detailed discussion.

3.44 percent annual rate in the first quarter of the simulation without affecting compensation per manhour or domestic nonfarm prices, since $P_{\text {con }}$ enters the wage equation only with a lag. In the second quarter the rate of wage change rises by about one-half percent (at annual rates) and prices by about one-sixth percent. The feedbacks between these equations continue and eventually the rate of increase of both prices and wages settles at a level about 0.4 percent above that in the simulation without the price disturbance.

These results obtain, of course, only in a wage-price sector in isolation. Table 2 can be regarded as an approximation to what would happen in the full system only if monetary and fiscal policy were managed in such a way as to offset the effects of the price disturbance on unemployment, the ratio of unfilled orders to shipments, and productivity. If policy were not so accommodating, the rise in prices would drive interest rates up, production down, and the unemployment rate up, thus reducing the upward pressure 
on prices. In fact, if the money stock were not expanded, output would have to remain at a reduced level until both the level and the rate of change of prices returned to the values they would have attained in the absence of the original disturbance in prices.

There is reason to suspect that wages may be less responsive to external price shocks than this model indicates. We do not know exactly what role the rate of change of prices plays in the wage equation. If it captures changes in the bargaining position of labor, a rise in import prices will have weaker effects than one in domestic prices because the value of the marginal product of labor will not have risen. Furthermore, to the extent that the coefficient represents wage earners' expectations of future inflation, one might question whether an increase in prices due to something like the formation of a cartel by the oil-producing countries would be extrapolated in the manner the price term indicates. After all, the industry cannot be cartelized more than once. To the extent that wage earners are aware of the source of the initial rise in price, they may not react as strongly as the wage equation implies.

In a similar vein, it has been argued that expectations are based not only on past values of the variable in question, but also on knowledge of the structure of the economic system and of the reactions of policy makers. Suppose people expect the authorities to increase the unemployment rate to, say, 6 percent and hold it there whenever inflation exceeded some maximum acceptable value. When this point is reached, individuals would reason that the authorities would not allow this situation to continue indefinitely, but would act to reduce the inflation rate slowly. In this case, price expectations would not depend upon previous prices alone, as they do in the wage equation used here.

\section{The Effects of External Shocks on the Economy as a Whole}

In this and the next section we report simulations of the full MPS model to analyze the effects of two price shocks to the economy: cartelization in the foreign oil-producing countries and the application of price controls. The emphasis will be on the interaction among the sectors of the economy, and on determining the pressures that would develop, under the assumption that monetary policy, as measured by growth in $\mathbf{M}_{1}$ (currency plus demand de- 
posits), does not respond to the shock. Fiscal policy, too, is assumed to remain unchanged. ${ }^{12}$

The degree to which policy should adjust to each of these shocks depends upon one's preferences concerning the tradeoff between unemployment and inflation. We have nothing to add to this debate. In a later section, however, we do discuss the impact of an "accommodating" monetary policy on the initial effects of a rise in oil prices.

In carrying out the experiments, we first simulated each of the model equations separately using actual values of the right-hand variables, and recorded the errors for each equation for each quarter. Next, we simulated the equations simultaneously in the full model using values of the variables that were calculated by the model on the right-hand side, adding in each quarter the error made by that equation when it was simulated separately. Because each equation simulated in this manner tracks the actual values exactly, the system tracks exactly. In the third simulation we entered some disturbance (for example, a change in the price of oil) and measured its effect by noting the difference between the second and third simulations.

This procedure has two advantages. First, because the model is nonlinear, its responses vary with the conditions under which the response is tested. Feeding the errors into each equation permits a test near historical values of the endogenous variables even in the face of serious equation errors. Second, and equally important, it allows us to modify various equations arbitrarily and still remain near historical values of the relevant endogenous variables. Otherwise it would be necessary to reestimate the equations involved.

An example should demonstrate the importance of this procedure for modifying the model's structure. Suppose that we have measured the response of the system to a change in the money stock. We now wish to know how the system would have reacted to the same change if the interest

12. We defined an unchanged fiscal policy as consisting of (1) unchanged tax rates (tax collections are allowed to vary with income), (2) unchanged constant-dollar federal purchases (current-dollar purchases of goods move proportionally to the nonfarm business deflator, and employee compensation moves proportionally to the private compensation rate), and (3) unchanged current-dollar transfer payments. The last of these assumptions is debatable in this context and so we repeated some of the experiments using an assumption of unchanged constant-dollar transfers, with negligible differences in the results. 
elasticity of demand for money were half the value specified in the money demand equation. With the interest elasticity coefficient cut in half, we simulate the altered money demand equation using actual variables on the right-hand side, and record the error for each quarter in place of the errors arising from the unaltered equation. Simulating the new system simultaneously, we add the new set of errors to each equation in each quarter. As in the test of the unaltered system, this second simulation will track history exactly. In the third simulation we again change the money stock and note the difference between the second and third simulations. We should find a greater effect on interest rates than we found in the unaltered system since now interest rates will need to change more in order to accommodate the changed money stock. This technique can also be used to add a new variable arbitrarily to an equation. We shall make use of the capacity to modify the model in these ways later in this section in order to do sensitivity analyses with certain important parameters in the model.

\section{CARTELIZATION OF AN IMPORT INDUSTRY}

We shall attempt to estimate the economic impact of the increase in crude oil prices from about $\$ 3.50$ to about $\$ 10$ per barrel that occurred in 1973 after the formation of the oil production cartel. We have ignored the effects of the temporary embargo on oil shipments to the United States, which, while sharp, were probably not abiding.

To some extent the results of the increase in oil prices will depend on price and income elasticities of demand that at this point are uncertain, on cross elasticities of demand between energy sources, and on the existence of backup energy technologies about which very little is known. Some sweeping assumptions about these matters are necessary: (1) that the cartelization will be permanent; (2) that the cartel will adjust the dollar price of oil in response to changes in the U.S. price level to maintain the relative prices of U.S. goods and oil; (3) that the price elasticity of demand for oil is low; (4) that the suppliers of imported oil are willing to take financial claims in payment and not spend them for U.S. exports. We also assume a world of floating exchange rates in which both import and export prices move proportionately with the domestic nonfarm business deflator. In this case a general inflation has no price effects on the quantities of internationally traded goods consumed. The effect of 
real income on import demand remains in force. Finally, we assume away all third-country effects.

Because of technical difficulties in simulating events into the relatively distant future, and because we wished to use the error coding procedure described earlier when altering the structure of the model, we moved cartelization and the oil crisis back to the beginning of $1967 . .^{13}$ This procedure allows us to simulate the effects of the oil case for seven years, which is probably much longer than several of our assumptions could be maintained. ${ }^{14}$

A necessary first step in the analysis is to determine the initial impact of the increase in prices of imported oil on U.S. prices. In principle we could calculate how much this increase adds to the current bills for imports and for final goods and raise the various price deflators for 1967 accordingly. However, this procedure cannot be used for different components of final output because we do not have complete information about how the increase is distributed among the price deflators for various products. Clearly, consumer nondurables and services bear the brunt of it. In addition to the substantial portion of petroleum used by private automobiles, much of the product of industries that rely heavily on petroleum, such as air transport and electric utilities, falls into these categories. For simplicity we assume that all of the increase in import prices is initially reflected in these sectors. On this assumption, the deflator for consumer nondurables and services would rise by about 2 percent. Since the valueadded deflator $\left(P_{n f}\right)$ is not affected directly, we altered equation (5) by increasing $U_{c n d}$ by 2 percent above its historical value. ${ }^{15}$

In fact, oil prices did not rise to their ultimate level all at once. Moreover, since the simultaneous embargo on shipments to the United States by some producer countries reduced the quantity of imported oil, the initial direct effect of the higher world prices for crude oil on the domestic price level was less severe than the above calculations imply. To allow for this we phased in the upward adjustment in equal increments over three quar-

13. Economic conditions obviously were not the same in 1967 as they are in 1974. Some evidence on the importance of initial conditions for the simulation results is discussed below.

14. Several of the equations use nominal interest rates prior to 1967 and real interest rates thereafter, so an earlier starting date was not feasible.

15. Then, since we wanted the deflator for domestically produced nondurable goods $\left(\boldsymbol{P}_{c n d} c_{n d}-\boldsymbol{P}_{i m} i m\right)$ to be unaffected by the oil price increase, we calculated the value of $P_{i m}$ that gave this result. 
ters, with the ratio $U_{c n d}$ maintained 2 percent higher in every quarter thereafter.

These procedures still leave the problem of pricing domestic oil and substitutes and of distributing this price increase by final product. By mid-1974, the average price of domestic oil had risen about $\$ 3$ a barrel in the wake of the rise in the price of imported oil. Domestic price controls, of course, contained the rise, and once the furor over petroleum prices subsides, oil producers will probably be able to exact prices that are closer to world levels. The rise in domestic oil prices causes an increase in the nonfarm business deflator relative to wages, and in the profit share of total output. The prices of oil substitutes have also risen. The price of coal has risen substantially (as would the price of natural gas in the absence of regulation). These effects should also increase the price level and the profit share in these industries.

But even if the prices of oil and other energy sources go up and remain high, the share of profits in gross national product might not rise, except in the short run, by as much as the crude figures on oil revenues suggest. Expanded domestic production of oil, coal, and natural gas, along with the development of other energy sources, would have a depressing effect on both foreign and domestic oil prices. Not only will there be a substitution away from oil products to other energy products and to other expenditures but in the long run resources will be attracted by high profits until the marginal, if not the average, productivity of capital in the oil industry recedes to approximately that of other industries. Thus, in the long run the profit share in GNP will tend to return to the value it would have had in the absence of cartelization. However, we believe that oil producers will be more likely to be able to maintain the higher profitability of their industry than will other import-competing goods industries. Our belief rests on the fact that larger profits are really a rent of oil wells and that the rental price can remain high even though induced investment reduces the marginal product of capital in this industry.

Clearly, many of these issues are more political and technological than economic, and we are forced to fall back on assumption. We assume (1) that the world price of oil remains at its new level of $\$ 10$, and (2) that the increase in the profit share brought about by a rise in the average price of domestic crude oil from about $\$ 3.50$ to $\$ 6.30$ per barrel is permanent. Further expansion in the profit share, arising from the higher price of domestic petroleum substitutes and deregulation of both domestic crude 
oil and its substitutes, is assumed to be offset by heavier investment in energy industries and the development of new technologies. In the present state of the world, these assumptions could be outdated within weeks.

The next step is to approximate the impact of the increases in domestic oil prices on the relevant price deflators. The increase in the dollar value of domestic crude oil production is the equivalent of just over 1 percent of the current-dollar value of nonfarm domestic business output in 1973:4.16 To account for the assumed response of domestic oil prices, we adjusted the nonfarm business deflator equation so that the deflator was 1 percent higher relative to factor costs than was the case in the control simulations.

Like the prices of imported oil, those of domestic oil will not reach their new level all at once; furthermore, some time will elapse between the rise in the prices of imported oil and the increase in the prices to the final consumers of products made from it. To approximate this combination of factors, we adjusted the price equation upward by only 0.5 percent in the initial quarter, then gradually increased the adjustment to 1 percent. ${ }^{17}$

Raising the prices of both domestic and imported oil increases the deflators for consumer nondurables and services 3 percent relative to wages when the phased-in adjustments are complete. The price of general government holds relative to wages, and the product prices of the remaining sectors of the economy rise 1 percent relative to wages.

Implicit in these adjustments to the deflators are assumptions concerning various elasticities of demand for petroleum products and of supply of domestic oil. Are these elasticities reasonable? In the eight years ending in 1973, annual consumption of petroleum products rose just under 50 percent, from 3,749 million to 5,617 million barrels. Assume that the same rate of increase would have continued had it not been for the increase in oil

16. Projected production of domestic crude oil for early 1974 was about 11 million barrels per day, which at $\$ 3.50$ per barrel is valued at $\$ 14.1$ billion per year. At $\$ 6.30$ per barrel, the value would be $\$ 25.3$ billion per year. In the fourth quarter of 1973 private nonfarm domestic output was $\$ 1,073$ billion. Increasing this total by $\$ 11.2$ billion (25.3-14.1) while leaving real output unchanged would increase the domestic nonfarm price deflator by slightly over 1 percent.

17. The adjustment was made by adding to equation (4) a constant 0.005 in the initial quarter of the high-oil-price simulations and 0.003 in each quarter thereafter. Since the coefficient of the lagged dependent variable is 0.7 , the adjustment approaches $0.003 /(1.0-0.7)=0.01$, or 1 percent since the equation is in logarithms. 
prices. Further assume that consumer nondurables and services and nonfarm business output grow on average at the long-run natural rate of growth of the economy (around 3.5 percent per year)-that is, about 32 percent in the same period. Our import price adjustment of 2 percent in $U_{c n d}$ is correct only if the proportion of imported oil in total real consumption of nondurables and services remains constant; our domestic price adjustment of 1 percent in $P_{n f}$ is correct only if domestic oil production is a constant proportion of nonfarm business output. For all these assumptions to be met, both imported oil consumption and domestic oil production must also increase by 32 percent over the period. Thus, we have implicitly assumed that the quantity of oil consumed will be reduced by 12.0 percent over the next eight years-that is, from 150 percent of its 1973 level to 132 percent. We estimate the average final sale price of petroleum products in 1973 to be roughly 30 cents per gallon; the price increases we are assuming will raise the average retail value by 10 cents per gallon, or 33 percent. The assumed long-run (eightyear) price elasticity of demand is then $-12 / 33$, or about -0.36 . This figure is perhaps a bit on the low side, but not improbable.

Next, is the assumption of a rate of growth of domestic petroleum output of about 3.5 percent reasonable? Domestic production actually declined slightly between 1970 and 1973 and if the world price of oil had not risen, the decline would probably have accelerated. Thus our assumptions imply a sizable price effect on domestic production. Imported petroleum, on the other hand, grew at about a 12 percent annual rate in the eight years ended in 1973. Our assumptions imply that this rate of growth drops to about 3.5 percent, which again is a substantial effect.

The oil price increase would also be expected to stimulate investment. For a time capital expenditures will be necessary to expand domestic oil output, to develop new energy resources, to expand production of petroleum substitutes, and to adopt energy-saving technology. We do not know the magnitudes of these effects and have not attempted to change the investment function to account for them. The function does allow investment to respond to changes in output and the cost of capital in response to the rise in oil prices.

The assumptions we have had to make are more likely to hold in the short run than over a longer period of years. Small errors in the assumed demand and supply elasticities will loom large with the passage 
Table 3. Simulated Economic Impact of the 1973 Increase in Oil Prices, by Selected Quarters

Deviation from control simulation

\begin{tabular}{|c|c|c|c|c|c|c|}
\hline \multirow{2}{*}{$\begin{array}{c}\text { Quarter } \\
\text { of } \\
\text { simu- } \\
\text { lation }\end{array}$} & \multicolumn{2}{|c|}{ Gross national product } & \multirow{2}{*}{$\begin{array}{l}\text { Consump- } \\
\text { tion ex- } \\
\text { penditures } \\
\text { (billions } \\
\text { of } 1958 \\
\text { dollars) }\end{array}$} & \multirow{2}{*}{$\begin{array}{c}\text { Disposable } \\
\text { income } \\
\text { (billions } \\
\text { of } 1958 \\
\text { dollars) }\end{array}$} & \multirow{2}{*}{$\begin{array}{l}\text { Unem- } \\
\text { ploy- } \\
\text { ment } \\
\text { rate } \\
(\text { per- } \\
\text { cent })\end{array}$} & \multirow[b]{2}{*}{$\begin{array}{c}\text { Treasury } \\
\text { bill rate } \\
\text { (percent) }\end{array}$} \\
\hline & $\begin{array}{l}\text { Billions } \\
\text { of current } \\
\text { dollars }\end{array}$ & $\begin{array}{l}\text { Billions } \\
\text { of } 1958 \\
\text { dollars }\end{array}$ & & & & \\
\hline 1 & 0.1 & -2.5 & -2.7 & -5.5 & 0.1 & 0.3 \\
\hline 2 & -3.1 & -6.0 & -5.3 & -10.2 & 0.4 & 0.3 \\
\hline 3 & -7.2 & -10.0 & -8.3 & -14.7 & 0.6 & 0.3 \\
\hline 4 & -10.4 & -13.4 & -10.4 & -16.4 & 0.9 & 0.2 \\
\hline 5 & -13.4 & -16.4 & -12.4 & -18.2 & 1.1 & 0.1 \\
\hline 6 & -16.4 & -19.1 & -14.3 & -20.0 & 1.3 & 0.0 \\
\hline 7 & -18.6 & -20.8 & -15.8 & -21.4 & 1.5 & -0.1 \\
\hline 8 & -20.0 & -21.5 & -16.9 & -22.7 & 1.6 & -0.2 \\
\hline 12 & -16.2 & -15.2 & -17.2 & -23.9 & 1.5 & -0.2 \\
\hline 16 & -21.6 & -14.4 & -18.2 & -24.7 & 1.7 & -0.3 \\
\hline 20 & -33.7 & -15.1 & -17.4 & -25.4 & 1.8 & -0.7 \\
\hline 24 & -57.3 & -19.5 & -18.6 & -28.3 & 2.1 & -1.2 \\
\hline 28 & -75.5 & -12.9 & -17.1 & -28.1 & 1.9 & -2.4 \\
\hline
\end{tabular}

Source: Simulations covering the 1967-73 period; the price of oil rises from $\$ 3.50$ to $\$ 10.00$ per barrel for imports and to $\$ 6.30$ per barrel for domestic production, as described in the text, while the money supply and fiscal policy are unchanged from the control simulation.

of time. The success of the foreign oil cartel is harder to predict the further ahead one looks. And investment response is likely to become more significant after a period of time. For all these reasons, the analysis is probably considerably more reliable for the near term than for several years down the road.

\section{SIMULATION RESULTS}

The problem has now been defined and we can turn to a series of simulation experiments designed to give quantitative estimates of the impacts of the rise in oil prices. Table 3 shows the differences between the highoil-price and control simulations. Initially, the higher oil prices powerfully depress income and employment, for several reasons.

First, the increase in import prices alone, when fully passed on to 


\begin{tabular}{|c|c|c|c|c|c|c|c|}
\hline \multicolumn{2}{|c|}{$\begin{array}{c}\text { Compensation per } \\
\text { manhour }\end{array}$} & \multicolumn{2}{|c|}{$\begin{array}{c}\text { Consumption price } \\
\text { deflator }\end{array}$} & \multirow[b]{2}{*}{$\begin{array}{c}\text { Exports } \\
\text { (billions } \\
\text { of } \\
\text { current } \\
\text { dollars) }\end{array}$} & \multirow[b]{2}{*}{$\begin{array}{l}\text { Imports } \\
\text { (billions } \\
\text { of } \\
\text { current } \\
\text { dollars) }\end{array}$} & \multirow{2}{*}{$\begin{array}{c}\text { Corporate } \\
\text { profits } \\
\text { (billions } \\
\text { of } \\
\text { current } \\
\text { dollars) }\end{array}$} & \multirow{2}{*}{$\begin{array}{c}\text { Value of } \\
\text { corporate } \\
\text { shares } \\
\text { (billions } \\
\text { of } \\
\text { current } \\
\text { dollars) }\end{array}$} \\
\hline $\begin{array}{l}\text { Amount } \\
\text { (cents) }\end{array}$ & $\begin{array}{l}\text { Annual } \\
\text { rate of } \\
\text { change } \\
\text { (percent) }\end{array}$ & $\begin{array}{c}\text { Index } \\
(1958= \\
100)\end{array}$ & $\begin{array}{l}\text { Annual } \\
\text { rate of } \\
\text { change } \\
\text { (percent) }\end{array}$ & & & & \\
\hline-0.3 & -0.4 & 1.2 & 4.2 & 0.2 & 2.7 & 1.2 & 18.6 \\
\hline-0.3 & 0.0 & 2.1 & 3.1 & 0.3 & 5.2 & 0.1 & 16.7 \\
\hline-0.2 & 0.1 & 2.9 & 2.5 & 0.3 & 7.3 & -1.4 & 5.7 \\
\hline 0.1 & 0.4 & 3.0 & 0.5 & 0.4 & 6.7 & -2.6 & 3.6 \\
\hline 0.1 & 0.0 & 3.1 & 0.2 & 0.4 & 6.4 & -3.1 & 9.1 \\
\hline-0.1 & -0.2 & 3.2 & 0.0 & 0.4 & 6.1 & -3.3 & 21.2 \\
\hline-0.4 & -0.4 & 3.2 & -0.1 & 0.5 & 6.0 & -2.9 & 31.6 \\
\hline-1.0 & -0.6 & 3.2 & -0.2 & 0.4 & 6.0 & -1.7 & 56.5 \\
\hline-3.6 & -0.7 & 2.9 & -0.4 & 0.4 & 7.2 & 7.9 & 99.2 \\
\hline-6.0 & -0.7 & 2.2 & -0.8 & -0.0 & 7.5 & 10.8 & 83.3 \\
\hline-11.0 & -1.2 & 0.8 & -1.2 & -0.6 & 7.3 & 12.9 & 84.0 \\
\hline-19.0 & -1.8 & -1.3 & -1.7 & -1.9 & 5.3 & 13.5 & 62.4 \\
\hline-30.7 & -2.3 & -4.5 & -2.2 & -4.9 & 4.4 & 27.3 & 92.4 \\
\hline
\end{tabular}

consumers, reduces real disposable income by about 1.8 percent ${ }^{18}$ _equivalent in effect to a 12 percent income tax surcharge at 1973:4 levels of the relevant magnitudes. Second, the increase in prices of domestic oil further depresses real disposable income by about 0.9 percent. Some of this loss will be returned to individuals in the form of dividends and, therefore, does not have quite the depressing effect of the increase in

18. The 1.8 percent is the proportion by which current-dollar disposable income in 1973:4 ( $\$ 917.8$ billion) would have had to rise to cover the increased price of imported oil ( $\$ 16.6$ billion). This, like other direct effects discussed here, cannot be read from the tables. The figures in the tables are the result of a simultaneous solution of the full system. The change in disposable income reported there is a result not only of the direct effect of the increase in oil prices on disposable income, but of indirect effects as well, since changed prices and real incomes lead first to changed production and then to further changes in disposable income. 
import prices. Moreover, the higher domestic prices will also enhance share prices and reduce the costs of capital, thus inducing more investment.

Third, the increased prices of imports also diminish the value of household net worth measured in terms of consumer goods. In the early quarters of the simulation, this accounts for about $\$ 2$ billion (1958 prices) of the reduced consumption in the simulation. Fourth, the increased prices for domestic oil further cut the real value of consumer net worth; again the effects are not as severe as those imposed by higher prices for imports because the richer profits of oil companies support the value of the corporateshare portion of consumer net worth. Finally, once the phase-in of oil prices is complete, the increase in the value of transactions raises the demand for money by enough to increase the Treasury bill rate by 60 basis points. These five effects combine to exert a powerful downward force on real output and consumption.

Unlike most downward shifts in real demand, that resulting from the increase in oil prices does not lead quickly to lower interest rates for a given growth in $\mathrm{M}_{1}$. In fact, the bill rate is not significantly lower until the fifth year of the simulation. There are two reasons for this slow reduction. First, higher prices raise the value of transactions, and interest rates cannot fall until real output and prices have dropped sufficiently to bring the value of transactions below the levels in the control simulation. Second, the increase in prices sets up an interaction that keeps compensation per manhour up to around its control levels for the first six quarters, and holds consumer prices above their control levels for five years. These higher prices also support interest rates, depriving the system for some time of the stabilizing effects the financial sector ordinarily offers when real activity declines. Thus, the multiplier-accelerator process is allowed to go farther than usual.

Given our assumptions of unchanged money growth, the rate of inflation eventually must return to its original level. This process takes a very long time to work itself out. The rise in oil prices raises the overall price level above a point that can be supported by the existing money stock. The curtailed output and unemployment eventually act to lower the rate of inflation as the economy tries to squeeze out the excess in prices. By the time it succeeds, however, the annual rate of inflation has been reduced by almost 2 percent and prices overshoot the mark. At the end of the simulation period, output is recovering. ${ }^{19}$

19. Real GNP is not down by nearly as much as the 1.9 percent higher unemployment rate would imply, given Okun's law. Among the reasons for this development two are especially important: (1) By the end of the simulation, the product of state and local 
This overshoot of the price level is surprising at first glance. It is, however, an almost inescapable result of the standard economic model. Suppose we have an economic system growing along an equilibrium path and for some reason the price level is displaced upward. If the money stock is not adjusted to accommodate this development, interest rates will rise, depressing the level of real output. In turn, unemployment will rise, and begin to restrain the rate of change of wages and prices. As long as prices are too high (and therefore output and employment too low) to be consistent with the equilibrium growth path, the rate of change of prices will decline. When prices finally return to the level they would have occupied in the absence of the disturbance, their rate of change is too low and they overshoot. The process then reverses. If the system is stable, both the level and the rate of change of prices will eventually achieve their equilibrium values. There is no guarantee that this cyclical mechanism is stable, and in the MPS model, it is barely so. The model may not pinpoint the time at which this price overshoot occurs, but simulations over a period long enough for the overshoot to occur serve to show how the adjustment works.

Eventually the inflation rate, unemployment, real output, and the bill rate must return to the neighborhood of their control levels. Because the value of transactions has risen, nominal GNP, prices, and wages must settle somewhat below control simulation levels. The simulation is not long enough for all these events to work themselves out.

The deflationary power of the oil crisis turns out to be substantial. In particular, the reduction in real output is sufficient to restrain wages in the early quarters of the simulation. This sharp reaction could be excessive. If prices of consumer goods increase, is it reasonable to believe that households rapidly adjust their consumption to the fall in the real value of their assets, as the model predicts?

\section{TESTS OF SENSITIVITY}

To test the importance of this factor in the simulation result, we altered the reaction of the consumption function to changes in real net worth. In

general government is lower and private business output is higher in the case involving higher oil prices. Real output per employee is much higher in the private sector than in the government sector. (2) Labor productivity in this model depends positively on the level of capacity utilization; when utilization is high, overhead employees are used more effectively. The lower real output in the early quarters of the oil simulations reduces the ending level of capacity and raises utilization rates. 
the first three years of the simulation, current-dollar net worth excluding common stocks $(V O W)$ was virtually unchanged by the increase in oil prices. Thereafter it dropped slightly, with the reduction not reaching $\$ 50$ billion until the fifth year. Thus, nearly all the reduction in real net worth in the early part of the simulations is caused by higher prices of consumer goods. To test the contribution that the rapid response of real consumption to the reduction in real net worth made to the simulation results, we merely suspended the term on $V O W$ in the consumption function by setting its coefficient to zero. This is equivalent to assuming that households never react to the fall in the real value of $V O W$.

The results of this test are shown in Table 4. As expected, the initial downward effect on consumption is mitigated, and the initial upward effects on prices and wages are magnified. The differences are not great, however. After a few quarters, Table 4 looks much like Table 3. Also,

\section{Table 4. Simulated Economic Impact of the Increase in Oil Prices} with a Modified Consumption Function, by Selected Quarters

Deviation from control simulation

\begin{tabular}{|c|c|c|c|c|c|c|}
\hline \multirow[b]{2}{*}{$\begin{array}{c}\text { Quarter } \\
\text { of } \\
\text { simu- } \\
\text { lation }\end{array}$} & \multicolumn{2}{|c|}{ Gross national product } & \multirow{2}{*}{$\begin{array}{c}\text { Consump- } \\
\text { tion ex- } \\
\text { penditures } \\
\text { (billions } \\
\text { of } 1958 \\
\text { dollars) }\end{array}$} & \multirow{2}{*}{$\begin{array}{c}\text { Disposable } \\
\text { income } \\
\text { (billions } \\
\text { of 1958 } \\
\text { dollars) }\end{array}$} & \multirow{2}{*}{$\begin{array}{l}\text { Unem- } \\
\text { ploy- } \\
\text { ment } \\
\text { rate } \\
(\text { per- } \\
\text { cent })\end{array}$} & \multirow[b]{2}{*}{$\begin{array}{c}\text { Treasury } \\
\text { bill rate } \\
\text { (percent) }\end{array}$} \\
\hline & $\begin{array}{l}\text { Billions } \\
\text { of current } \\
\text { dollars }\end{array}$ & $\begin{array}{l}\text { Billions } \\
\text { of } 1958 \\
\text { dollars }\end{array}$ & & & & \\
\hline 1 & 1.3 & -1.5 & -1.6 & -5.1 & 0.1 & 0.3 \\
\hline 2 & 0.2 & -3.4 & -3.1 & -9.1 & 0.2 & 0.4 \\
\hline 3 & -1.6 & -6.1 & -5.1 & -12.9 & 0.4 & 0.6 \\
\hline 4 & -3.4 & -8.7 & -6.7 & -14.2 & 0.5 & 0.5 \\
\hline 5 & -5.4 & -11.5 & -8.5 & -15.7 & 0.7 & 0.5 \\
\hline 6 & -7.7 & -14.2 & -10.2 & -17.5 & 0.9 & 0.4 \\
\hline 7 & -9.6 & -16.2 & -11.5 & -18.9 & 1.1 & 0.4 \\
\hline 8 & -10.8 & -17.5 & -12.6 & -20.1 & 1.2 & 0.4 \\
\hline 12 & -10.7 & -16.7 & -14.6 & -23.0 & 1.4 & 0.5 \\
\hline 16 & -14.9 & -17.6 & -16.4 & -24.8 & 1.7 & 0.1 \\
\hline 20 & -24.6 & -19.8 & -17.5 & -27.0 & 2.0 & -0.2 \\
\hline 24 & -48.8 & -27.5 & -20.9 & -32.7 & 2.5 & -1.0 \\
\hline 28 & -63.1 & -20.5 & -20.7 & -34.0 & 2.5 & -2.0 \\
\hline
\end{tabular}

Source: Simulations covering the 1967-73 period. Changes in real consumer net worth other than common stocks are assumed to have no effect on consumption. Changes in oil prices and assumptions about policy are the same as those for Table 3. 
while the early effects are moderated by this change, the later effects are intensified. These shifts result because prices in this simulation have risen even farther above the level that can be supported by the existing money stock.

Certainly the correct specification of the consumption function is closer to the one used in Table 3 than to that in Table 4. This test demonstrates that the results reported in Table 3 would not be significantly altered by any reasonable slowing of the reaction of the consumption function to changes in net worth.

We also tested the sensitivity of the results to our selection of imports plus GNP as the appropriate measure of transactions in the money demand function. The test consisted of dropping the modified money demand equation and repeating the experiment with the original money demand function, in which transactions are represented by nominal GNP. The re-

\begin{tabular}{|c|c|c|c|c|c|c|c|}
\hline \multicolumn{2}{|c|}{$\begin{array}{l}\text { Compensation per } \\
\text { manhour }\end{array}$} & \multicolumn{2}{|c|}{$\begin{array}{c}\text { Consumption price } \\
\text { deflator }\end{array}$} & \multirow[b]{2}{*}{$\begin{array}{c}\text { Exports } \\
\text { (billions } \\
\text { of } \\
\text { current } \\
\text { dollars) }\end{array}$} & \multirow{2}{*}{$\begin{array}{l}\text { Imports } \\
\text { (billions } \\
\text { of } \\
\text { current } \\
\text { dollars) }\end{array}$} & \multirow{2}{*}{$\begin{array}{c}\text { Corporate } \\
\text { profits } \\
\text { (billions } \\
\text { of } \\
\text { current } \\
\text { dollars) }\end{array}$} & \multirow{2}{*}{$\begin{array}{c}\text { Value of } \\
\text { corporate } \\
\text { shares } \\
\text { (billions } \\
\text { of } \\
\text { current } \\
\text { dollars) }\end{array}$} \\
\hline $\begin{array}{l}\text { Amount } \\
\text { (cents) }\end{array}$ & $\begin{array}{l}\text { Annual } \\
\text { rate of } \\
\text { change } \\
\text { (percent) }\end{array}$ & $\begin{array}{c}\text { Index } \\
(1958= \\
100)\end{array}$ & $\begin{array}{l}\text { Annual } \\
\text { rate of } \\
\text { change } \\
\text { (percent) }\end{array}$ & & & & \\
\hline-0.1 & -0.2 & 1.2 & 4.3 & 0.2 & 2.8 & 1.7 & 19.6 \\
\hline 0.1 & 0.3 & 2.2 & 3.3 & 0.3 & 5.6 & 1.1 & 17.9 \\
\hline 0.5 & 0.5 & 3.0 & 2.8 & 0.3 & 8.0 & -0.1 & 5.8 \\
\hline 1.1 & 0.7 & 3.3 & 0.8 & 0.4 & 7.6 & -1.2 & 2.8 \\
\hline 1.5 & 0.4 & 3.5 & 0.5 & 0.5 & 7.4 & -2.0 & 7.3 \\
\hline 1.6 & 0.1 & 3.6 & 0.4 & 0.6 & 7.2 & -2.4 & 16.7 \\
\hline 1.7 & 0.0 & 3.8 & 0.3 & 0.7 & 7.1 & -2.4 & 25.8 \\
\hline 1.5 & -0.2 & 3.9 & 0.2 & 0.7 & 7.1 & -1.9 & 44.8 \\
\hline 0.4 & -0.4 & 4.2 & -0.1 & 0.8 & 7.9 & 3.0 & 64.9 \\
\hline-0.6 & -0.3 & 4.0 & -0.3 & 0.7 & 8.2 & 5.1 & 55.6 \\
\hline-3.8 & -0.9 & 3.2 & -0.9 & 0.3 & 8.1 & 7.9 & 49.0 \\
\hline-10.5 & -1.7 & 1.5 & -1.5 & -0.6 & 5.8 & 9.2 & 32.9 \\
\hline-21.4 & -2.3 & -1.4 & -2.1 & -2.8 & 5.0 & 27.8 & 94.9 \\
\hline
\end{tabular}


sults are reported in Table 5. A comparison with Table 3 indicates that the effects of this adjustment are not large. The modification works in the expected direction. The unemployment rate is not driven as high and the price level ends up somewhat higher.

It has sometimes been argued that the interaction between prices and wages depends upon whether the increase in prices originates within the nonfarm business sector or outside it. Prices can affect wages through two avenues: through demands by workers for higher wages to cover a rise in consumption prices, and through the willingness of firms to pay higher wages when the value of the marginal product of labor has risen. Price increases whose source is outside the nonfarm business sector do not raise the value of labor's marginal product and should, therefore, lead to smaller wage gains. Thus a price increase resulting from an external shock that raises $P_{\text {con }}$ and not $P_{n f}$ may not have as large an impact on wages, at least initially, as an ordinary rise in all prices. Because the correlation

\section{Table 5. Simulated Economic Impact of the Increase in Oil Prices} with a Modified Money Demand Equation, by Selected Quarters

Deviation from control simulation

\begin{tabular}{|c|c|c|c|c|c|c|}
\hline \multirow{2}{*}{$\begin{array}{c}\text { Quarter } \\
\text { of } \\
\text { simu- } \\
\text { lation }\end{array}$} & \multicolumn{2}{|c|}{ Gross national product } & \multirow{2}{*}{$\begin{array}{c}\text { Consump- } \\
\text { tion ex- } \\
\text { penditures } \\
\text { (billions } \\
\text { of } 1958 \\
\text { dollars) }\end{array}$} & \multirow{2}{*}{$\begin{array}{c}\text { Disposable } \\
\text { income } \\
\text { (billions } \\
\text { of } 1958 \\
\text { dollars) }\end{array}$} & \multirow{2}{*}{$\begin{array}{l}\text { Unem- } \\
\text { ploy- } \\
\text { ment } \\
\text { rate } \\
\text { (per- } \\
\text { cent })\end{array}$} & \multirow[b]{2}{*}{$\begin{array}{c}\text { Treasury } \\
\text { bill rate } \\
\text { (percent) }\end{array}$} \\
\hline & $\begin{array}{l}\text { Billions } \\
\text { of current } \\
\text { dollars }\end{array}$ & $\begin{array}{l}\text { Billions } \\
\text { of } 1958 \\
\text { dollars }\end{array}$ & & & & \\
\hline 1 & 0.2 & -2.4 & -2.6 & -5.5 & 0.1 & 0.1 \\
\hline 2 & -2.7 & -5.6 & -5.1 & -10.0 & 0.3 & 0.0 \\
\hline 3 & -6.1 & -9.1 & -7.9 & -14.3 & 0.6 & -0.1 \\
\hline 4 & -8.4 & -11.9 & -9.7 & -15.8 & 0.8 & -0.1 \\
\hline 5 & -10.5 & -14.3 & -11.5 & -17.4 & 1.0 & -0.2 \\
\hline 6 & -12.6 & -16.5 & -13.2 & -19.0 & 1.1 & -0.3 \\
\hline 7 & -14.0 & -17.8 & -14.5 & -20.2 & 1.3 & -0.3 \\
\hline 8 & -14.5 & -18.1 & -15.3 & -21.2 & 1.4 & -0.3 \\
\hline 12 & -5.5 & -9.7 & -14.6 & -21.4 & 1.2 & 0.0 \\
\hline 16 & -9.7 & -10.2 & -15.8 & -22.2 & 1.3 & -0.2 \\
\hline 20 & -17.5 & -10.6 & -14.8 & -22.9 & 1.4 & -0.5 \\
\hline 24 & -34.0 & -14.2 & -16.3 & -25.5 & 1.6 & -0.8 \\
\hline 28 & -52.0 & -12.6 & -17.0 & -26.8 & 1.6 & -1.9 \\
\hline
\end{tabular}

Source: Simulations covering the 1967-73 period. Money demand is assumed to be unaffected by higher import prices. Assumptions about the changes in oil prices and about policy are the same as those for Table 3. 
between consumption prices and nonfarm business prices is very close, their differential effects are difficult to estimate; we were in fact unable to do so. The question is critical to our discussion, however, so we decided to test how much difference it might make if the price effect estimated in the model (which used consumer prices only) were in fact distributed between consumer and producer prices.

We again arbitrarily altered the original form of the model by breaking the long-run price coefficient of 0.989 in the wage equation into two parts. We entered two price terms with the same distributed lag into the equation. The first term was on the rate of change of the nonfarm business deflator, and we gave this term a coefficient of 0.5 . The other distributed lag was on the rate of change of $P_{\text {con }}$, and we gave this term a coefficient of 0.489 . Simulation results with this modification to the wage equation are reported in Table 6.

As expected, this change helps repress the rate of wage inflation in the

\begin{tabular}{|c|c|c|c|c|c|c|c|}
\hline \multicolumn{2}{|c|}{$\begin{array}{c}\text { Compensation per } \\
\text { manhour }\end{array}$} & \multicolumn{2}{|c|}{$\begin{array}{c}\text { Consumption price } \\
\text { deflator }\end{array}$} & \multirow[b]{2}{*}{$\begin{array}{l}\text { Exports } \\
\text { (billions } \\
\text { of } \\
\text { current } \\
\text { dollars) }\end{array}$} & \multirow[b]{2}{*}{$\begin{array}{c}\text { Imports } \\
\text { (billions } \\
\text { of } \\
\text { current } \\
\text { dollars) }\end{array}$} & \multirow{2}{*}{$\begin{array}{c}\text { Corporate } \\
\text { profits } \\
\text { (billions } \\
\text { of } \\
\text { current } \\
\text { dollars) }\end{array}$} & \multirow{2}{*}{$\begin{array}{c}\text { Value of } \\
\text { corporate } \\
\text { shares } \\
\text { (billions } \\
\text { of } \\
\text { current } \\
\text { dollars) }\end{array}$} \\
\hline $\begin{array}{l}\text { Amount } \\
\text { (cents) }\end{array}$ & $\begin{array}{l}\text { Annual } \\
\text { rate of } \\
\text { change } \\
\text { (percent) }\end{array}$ & $\begin{array}{c}\text { Index } \\
(1958= \\
100)\end{array}$ & $\begin{array}{l}\text { Annual } \\
\text { rate of } \\
\text { change } \\
\text { (percent) }\end{array}$ & & & & \\
\hline-0.3 & -0.3 & 1.2 & 4.2 & 0.2 & 2.7 & 1.3 & 19.5 \\
\hline-0.3 & 0.0 & 2.1 & 3.1 & 0.3 & 5.3 & 0.3 & 22.0 \\
\hline-0.1 & 0.2 & 2.8 & 2.5 & 0.3 & 7.4 & -0.9 & 14.2 \\
\hline 0.2 & 0.5 & 3.0 & 0.6 & 0.4 & 6.9 & -1.8 & 13.2 \\
\hline 0.4 & 0.2 & 3.2 & 0.3 & 0.4 & 6.7 & -2.1 & 18.4 \\
\hline 0.3 & -0.1 & 3.3 & 0.2 & 0.5 & 6.5 & -2.1 & 32.4 \\
\hline 0.2 & -0.2 & 3.3 & 0.1 & 0.5 & 6.5 & -1.6 & 45.3 \\
\hline-0.2 & -0.4 & 3.3 & -0.1 & 0.5 & 6.5 & -0.3 & 73.7 \\
\hline-1.5 & -0.3 & 3.4 & -0.1 & 0.6 & 8.3 & 9.5 & 122.3 \\
\hline-2.6 & -0.4 & 3.0 & -0.6 & 0.4 & 8.6 & 10.4 & 105.9 \\
\hline-6.1 & -0.8 & 2.1 & -0.7 & 0.0 & 8.8 & 12.0 & 121.0 \\
\hline-11.7 & -1.4 & 0.8 & -1.2 & -0.8 & 7.6 & 12.0 & 103.0 \\
\hline-20.8 & -1.8 & -1.6 & -1.7 & -2.8 & 6.4 & 20.9 & 107.5 \\
\hline
\end{tabular}


Table 6. Simulated Economic Impact of the Increase in Oil Prices with a Modified Wage Equation, by Selected Quarters

Deviation from control simulation

\begin{tabular}{|c|c|c|c|c|c|c|}
\hline \multirow{2}{*}{$\begin{array}{c}\text { Quarter } \\
\text { of } \\
\text { simu- } \\
\text { lation }\end{array}$} & \multicolumn{2}{|c|}{ Gross national product } & \multirow{2}{*}{$\begin{array}{c}\text { Consump- } \\
\text { tion ex- } \\
\text { penditures } \\
\text { (billions } \\
\text { of 1958 } \\
\text { dollars) }\end{array}$} & \multirow{2}{*}{$\begin{array}{c}\text { Disposable } \\
\text { income } \\
\text { (billions } \\
\text { of } 1958 \\
\text { dollars) }\end{array}$} & \multirow{2}{*}{$\begin{array}{l}\text { Unem- } \\
\text { ploy- } \\
\text { ment } \\
\text { rate } \\
(\text { per- } \\
\text { cent })\end{array}$} & \multirow[b]{2}{*}{$\begin{array}{l}\text { Treasury } \\
\text { bill rate } \\
\text { (percent) }\end{array}$} \\
\hline & $\begin{array}{l}\text { Billions } \\
\text { of current } \\
\text { dollars }\end{array}$ & $\begin{array}{l}\text { Billions } \\
\text { of } 1958 \\
\text { dollars }\end{array}$ & & & & \\
\hline 1 & 0.1 & -2.5 & -2.7 & -5.5 & 0.1 & 0.3 \\
\hline 2 & -3.3 & -6.0 & -5.3 & -10.3 & 0.4 & 0.3 \\
\hline 3 & -7.8 & -10.1 & -8.4 & -15.0 & 0.6 & 0.3 \\
\hline 4 & -11.6 & -13.5 & -10.5 & -16.9 & 0.9 & 0.1 \\
\hline 5 & -15.3 & -16.4 & -12.6 & -18.8 & 1.1 & 0.0 \\
\hline 6 & -18.9 & -18.9 & -14.4 & -20.7 & 1.3 & -0.2 \\
\hline 7 & -21.8 & -20.5 & -15.8 & -22.0 & 1.4 & -0.3 \\
\hline 8 & -23.8 & -20.9 & -16.7 & -23.0 & 1.5 & -0.4 \\
\hline 12 & -21.0 & -12.3 & -15.8 & -23.1 & 1.4 & -0.5 \\
\hline 16 & -27.2 & -9.7 & -15.9 & -22.9 & 1.4 & -0.6 \\
\hline 20 & -40.8 & -9.1 & -13.8 & -22.1 & 1.4 & -0.9 \\
\hline 24 & -62.7 & -11.0 & -13.7 & -22.8 & 1.5 & -1.3 \\
\hline 28 & -78.1 & -3.4 & -11.3 & -20.6 & 1.1 & -2.4 \\
\hline
\end{tabular}

Source: Simulations covering the 1967-73 period. It is assumed that half the price effect on wages comes from consumer prices and half from producer prices. Assumptions about changes in oil prices and about policy are the same as those for Table 3 .

early part of the simulation. The adjustment to the increase in oil prices is less painful. The early rates of inflation are somewhat reduced and the maximum rise in unemployment in the later part of the simulations is considerably reduced. The most implausible feature of the simulation is that wage inflation is immediately reduced by the increase in oil prices. This may be possible, but seems unlikely. In any event, the modification of the wage equation does not produce a major change in the outcome.

We next modified the assumptions of the basic model to allow for a rise in exports in response to the dollar accumulations of oil-producing nations. In this variation, real exports slowly rose until the nominal value of the increment matched the increase in the value of imported oil. In the second quarter of the simulation, real exports were increased enough to push nominal exports up by 5 percent of the amount of the extra payments for oil imports in the first quarter of the simulation. In successive quarters, 


\begin{tabular}{|c|c|c|c|c|c|c|c|}
\hline \multicolumn{2}{|c|}{$\begin{array}{l}\text { Compensation per } \\
\text { manhour }\end{array}$} & \multicolumn{2}{|c|}{$\begin{array}{c}\text { Consumption price } \\
\text { deflator }\end{array}$} & \multirow[b]{2}{*}{$\begin{array}{l}\text { Exports } \\
\text { (billions } \\
\quad \text { of } \\
\text { current } \\
\text { dollars) }\end{array}$} & \multirow{2}{*}{$\begin{array}{l}\text { Imports } \\
\text { (billions } \\
\text { of } \\
\text { current } \\
\text { dollars) }\end{array}$} & \multirow{2}{*}{$\begin{array}{c}\text { Corporate } \\
\text { profits } \\
\text { (billions } \\
\text { of } \\
\text { current } \\
\text { dollars) }\end{array}$} & \multirow{2}{*}{$\begin{array}{l}\text { Value of } \\
\text { corporate } \\
\text { shares } \\
\text { (billions } \\
\text { of } \\
\text { current } \\
\text { dollars) }\end{array}$} \\
\hline $\begin{array}{l}\text { Amount } \\
(\text { cents })\end{array}$ & $\begin{array}{l}\text { Annual } \\
\text { rate of } \\
\text { change } \\
\text { (percent) }\end{array}$ & $\begin{array}{c}\text { Index } \\
(1958= \\
100)\end{array}$ & $\begin{array}{l}\text { Annual } \\
\text { rate of } \\
\text { change } \\
\text { (percent) }\end{array}$ & & & & \\
\hline-0.3 & -0.4 & 1.2 & 4.2 & 0.2 & 2.7 & 1.2 & 18.6 \\
\hline-0.5 & -0.2 & 2.1 & 3.1 & 0.2 & 5.2 & 0.3 & 16.7 \\
\hline-0.7 & -0.3 & 2.8 & 2.4 & 0.3 & 7.2 & -1.0 & 5.6 \\
\hline-0.9 & -0.2 & 2.9 & 0.2 & 0.3 & 6.6 & -1.9 & 3.9 \\
\hline-1.3 & -0.5 & 2.9 & -0.2 & 0.3 & 6.2 & -2.2 & 9.8 \\
\hline-1.9 & -0.7 & 2.8 & -0.4 & 0.3 & 5.9 & -2.1 & 22.8 \\
\hline-2.7 & -0.8 & 2.7 & -0.5 & 0.3 & 5.7 & -1.4 & 32.5 \\
\hline-3.7 & -1.1 & 2.5 & -0.7 & 0.2 & 5.7 & 0.0 & 58.5 \\
\hline-7.9 & -1.1 & 1.6 & -0.8 & -0.2 & 6.9 & 11.0 & 107.8 \\
\hline-11.8 & -1.0 & 0.4 & -1.2 & -0.7 & 7.2 & 15.1 & 85.9 \\
\hline-18.0 & -1.4 & -1.5 & -1.4 & -1.5 & 7.0 & 16.1 & 81.0 \\
\hline-26.1 & -1.7 & -3.6 & -1.6 & -3.1 & 5.4 & 15.5 & 52.6 \\
\hline-36.4 & -1.8 & -6.6 & -1.8 & -6.3 & 5.0 & 25.6 & 71.8 \\
\hline
\end{tabular}

this process was repeated, in 5 percent increments, until in the twenty-first quarter, the extra value of exports matched the increased oil payments.

The results of this experiment are reported in Table 7. Again they reflect no major departure from the results of Table 3 . Increasing exports lengthens the period of adjustment because aggregate demand does not fall as rapidly. Despite this upward shift in aggregate demand, the economy must endure sufficient unemployment to squeeze the excess inflation from prices. The adjustment, while reduced in magnitude, is extended in time. ${ }^{20}$

Initial conditions in the economy may be crucial to the issue of policy responses to the increase in oil prices. Conditions in 1967 obviously were not the same as those in 1974. In particular, the unemployment rate was

20. It appears that any adjustment in the investment function to allow for expanded oil exploration or coal mining, or for development of alternative energy technologies, would have similar effects. 
Table 7. Simulated Economic Impact of the Increase in Oil Prices with Rising U.S. Exports, by Selected Quarters

Deviation from control simulation

\begin{tabular}{|c|c|c|c|c|c|c|}
\hline \multirow{2}{*}{$\begin{array}{c}\text { Quarter } \\
\text { of } \\
\text { simu- } \\
\text { lation }\end{array}$} & \multicolumn{2}{|c|}{ Gross national product } & \multirow{2}{*}{$\begin{array}{c}\text { Consump- } \\
\text { tion ex- } \\
\text { penditures } \\
\text { (billions } \\
\text { of } 1958 \\
\text { dollars) }\end{array}$} & \multirow{2}{*}{$\begin{array}{c}\text { Disposable } \\
\text { income } \\
\text { (billions } \\
\text { of } 1958 \\
\text { dollars) }\end{array}$} & \multirow{2}{*}{$\begin{array}{l}\text { Unem- } \\
\text { ploy- } \\
\text { ment } \\
\text { rate } \\
\text { (per- } \\
\text { cent })\end{array}$} & \multirow[b]{2}{*}{$\begin{array}{c}\text { Treasury } \\
\text { bill rate } \\
\text { (percent) }\end{array}$} \\
\hline & $\begin{array}{l}\text { Billions } \\
\text { of current } \\
\text { dollars }\end{array}$ & $\begin{array}{l}\text { Billions } \\
\text { of } 1958 \\
\text { dollars }\end{array}$ & & & & \\
\hline 1 & 0.1 & -2.5 & -2.7 & -5.5 & 0.1 & 0.3 \\
\hline 2 & -2.8 & -5.7 & -5.3 & -10.1 & 0.3 & 0.3 \\
\hline 3 & -6.1 & -9.1 & -8.2 & -14.4 & 0.6 & 0.4 \\
\hline 4 & -8.5 & -12.0 & -10.1 & -15.9 & 0.8 & 0.3 \\
\hline 5 & -10.6 & -14.3 & -12.1 & -17.4 & 1.0 & 0.2 \\
\hline 6 & -12.6 & -16.4 & -13.8 & -18.9 & 1.1 & 0.1 \\
\hline 7 & -13.8 & -17.6 & -15.1 & -20.0 & 1.3 & 0.1 \\
\hline 8 & -14.2 & -18.0 & -16.0 & -21.0 & 1.4 & 0.1 \\
\hline 12 & -8.0 & -11.3 & -16.5 & -21.8 & 1.3 & 0.3 \\
\hline 16 & -9.3 & -9.6 & -17.3 & -22.3 & 1.3 & 0.1 \\
\hline 20 & -13.0 & -7.4 & -16.1 & -22.0 & 1.3 & -0.1 \\
\hline 24 & -27.0 & -9.7 & -16.6 & -23.8 & 1.4 & -0.6 \\
\hline 28 & -35.3 & -3.6 & -15.7 & -23.7 & 1.2 & -1.3 \\
\hline
\end{tabular}

Source: Simulations covering the $1967-73$ period. The value of exports is allowed to rise to match the higher value of oil imports. Assumptions about the changes in oil prices and about policy are the same as those in Table 3.

lower in 1967-69 than it has been recently. ${ }^{21}$ To examine this possibility, we conducted the experiment presented in Table 3 starting in the first quarter of 1970 rather than 1967 . This shift allows us to analyze the effects of an oil price increase under unemployment rates significantly higher than those in 1967. Of course, only four years could be simulated in this experiment. The results are reported in Table 8; again they reveal no major changes in the results. The most notable difference is that the price adjustment has been slowed since at higher unemployment rates the Phillips curve is flatter-that is, a given rise in the unemployment rate

21 If our model were linear, the results would not depend on initial conditions. This model, however, has a number of nonlinearities; the prime example is the Phillips curve since its usual hyperbolic formulation means much greater changes in inflation for given changes in the unemployment rate at low levels of unemployment than at high levels. 


\begin{tabular}{|c|c|c|c|c|c|c|c|}
\hline \multicolumn{2}{|c|}{$\begin{array}{l}\text { Compensation per } \\
\text { manhour }\end{array}$} & \multicolumn{2}{|c|}{$\begin{array}{c}\text { Consumption price } \\
\text { deflator }\end{array}$} & \multirow[b]{2}{*}{$\begin{array}{c}\text { Exports } \\
\text { (billions } \\
\quad \text { of } \\
\text { current } \\
\text { dollars) }\end{array}$} & \multirow[b]{2}{*}{$\begin{array}{l}\text { Imports } \\
\text { (billions } \\
\text { of } \\
\text { current } \\
\text { dollars) }\end{array}$} & \multirow{2}{*}{$\begin{array}{c}\text { Corporate } \\
\text { profits } \\
\text { (billions } \\
\text { of } \\
\text { current } \\
\text { dollars) }\end{array}$} & \multirow{2}{*}{$\begin{array}{c}\text { Value of } \\
\text { corporate } \\
\text { shares } \\
\text { (billions } \\
\text { of } \\
\text { current } \\
\text { dollars) }\end{array}$} \\
\hline $\begin{array}{l}\text { Amount } \\
\text { (cents) }\end{array}$ & $\begin{array}{l}\text { Annual } \\
\text { rate of } \\
\text { change } \\
\text { (percent) }\end{array}$ & $\begin{array}{c}\text { Index } \\
(1958= \\
100)\end{array}$ & $\begin{array}{l}\text { Annual } \\
\text { rate of } \\
\text { change } \\
\text { (percent) }\end{array}$ & & & & \\
\hline-0.3 & -0.4 & 1.2 & 4.2 & 0.2 & 2.7 & 1.2 & 18.6 \\
\hline-0.3 & 0.0 & 2.1 & 3.1 & 0.5 & 5.3 & 0.3 & 17.1 \\
\hline-0.1 & 0.2 & 2.9 & 2.6 & 1.1 & 7.4 & -0.9 & 6.8 \\
\hline 0.3 & 0.5 & 3.1 & 0.5 & 1.6 & 6.9 & -1.9 & 5.1 \\
\hline 0.4 & 0.2 & 3.2 & 0.3 & 2.1 & 6.7 & -2.2 & 11.1 \\
\hline 0.4 & -0.1 & 3.3 & 0.2 & 2.6 & 6.5 & -2.2 & 23.4 \\
\hline 0.2 & -0.2 & 3.4 & 0.1 & 3.1 & 6.5 & -1.6 & 34.8 \\
\hline-0.2 & -0.4 & 3.4 & 0.0 & 3.6 & 6.5 & -0.3 & 59.1 \\
\hline-1.5 & -0.4 & 3.5 & -0.2 & 5.8 & 7.9 & 8.3 & 89.9 \\
\hline-2.6 & -0.4 & 3.2 & -0.5 & 8.2 & 8.6 & 11.8 & 82.7 \\
\hline-5.6 & -0.7 & 2.4 & -0.7 & 11.0 & 9.1 & 15.2 & 91.5 \\
\hline-10.7 & -1.2 & 1.1 & -1.1 & 12.6 & 8.3 & 16.0 & 77.3 \\
\hline-18.4 & -1.4 & -0.9 & -1.4 & 14.0 & 8.6 & 29.8 & 91.7 \\
\hline
\end{tabular}

yields a smaller reduction in the inflation rate. This pattern makes the adjustment more difficult since a larger rise in unemployment must be endured to squeeze out the excess from prices. In this respect, 1974 is probably more like 1970 than like 1967.

\section{ACCOMMODATIVE MONETARY POLICY}

One obvious policy response to an event like the surge in oil prices would be to accommodate the original increase in prices with an expansion of the money stock. We could derive a monetary policy that maximizes an objective function based on, say, the unemployment rate and the rate of inflation. We have chosen not to attempt this, partly because we do not want to enter into a debate about the parameters of this objective function. Instead we have chosen to analyze the simple case in which the 
Table 8. Simulated Economic Impact of the Increase in Oil Prices with Differing Initial Economic Conditions, by Selected Quarters

Deviation from control simulation

\begin{tabular}{|c|c|c|c|c|c|c|}
\hline \multirow{2}{*}{$\begin{array}{l}\text { Quarter } \\
\text { of } \\
\text { simu- } \\
\text { lation }\end{array}$} & \multicolumn{2}{|c|}{ Gross national product } & \multirow{2}{*}{$\begin{array}{c}\text { Consump- } \\
\text { tion ex- } \\
\text { penditures } \\
\text { (billions } \\
\text { of } 1958 \\
\text { dollars) }\end{array}$} & \multirow{2}{*}{$\begin{array}{c}\text { Disposable } \\
\text { income } \\
\text { (billions } \\
\text { of } 1958 \\
\text { dollars) }\end{array}$} & \multirow{2}{*}{$\begin{array}{l}\text { Unem- } \\
\text { ploy- } \\
\text { ment } \\
\text { rate } \\
\text { (per- } \\
\text { cent) }\end{array}$} & \multirow[b]{2}{*}{$\begin{array}{c}\text { Treasury } \\
\text { bill rate } \\
\text { (percent) }\end{array}$} \\
\hline & $\begin{array}{l}\text { Billions } \\
\text { of current } \\
\text { dollars }\end{array}$ & $\begin{array}{l}\text { Billions } \\
\text { of } 1958 \\
\text { dollars }\end{array}$ & & & & \\
\hline 1 & -0.2 & -2.9 & -3.1 & -6.2 & 0.1 & 0.4 \\
\hline 2 & -4.3 & -6.9 & -6.0 & -11.1 & 0.3 & 0.5 \\
\hline 3 & -8.9 & -11.4 & -9.3 & -15.4 & 0.6 & 0.5 \\
\hline 4 & -11.8 & -14.7 & -10.9 & -15.8 & 0.8 & 0.4 \\
\hline 5 & -14.1 & -17.8 & -13.1 & -17.7 & 1.0 & 0.2 \\
\hline 6 & -16.6 & -20.9 & -15.2 & -19.1 & 1.2 & 0.2 \\
\hline 7 & -17.8 & -23.1 & -17.0 & -20.7 & 1.4 & 0.4 \\
\hline 8 & -18.0 & -24.7 & -18.6 & -22.3 & 1.5 & 0.3 \\
\hline 12 & -6.1 & -22.0 & -21.8 & -28.1 & 1.8 & 0.9 \\
\hline 16 & -12.1 & -27.6 & -25.9 & -32.9 & 2.3 & 1.1 \\
\hline
\end{tabular}

Source: Simulations starting with the economy of 1970 rather than 1967 . The assumptions about the changes in oil prices and about policy are the same as those in Table 3.

monetary authority responds by increasing the money stock in proportion to the increase in transactions demand-the sum of current-dollar GNP plus imports-resulting from the initial rise in prices for both imported and domestic oil. After this initial accommodation, the money stock is assumed to grow at its old constant rate. The results of this exercise are shown in Table 9. As expected, real output declines much less in this case.

A decline still occurs, of course, because even though the monetary authority has offset the impact of the original price increases on transactions, the system still reacts to the reduction in real income and wealth. The expansion in the money stock also allows the wage-price spiral to continue to a much greater extent. The average inflation rate over the seven-year period is about 0.7 percent higher than when the authorities do not accommodate the increase in transactions. In the long run, the inflation rate must return to its value in the control simulation. Achieving this result requires that the average unemployment rate be sufficiently high in the transition period. Whether or not the outcome of this "accommodating" monetary policy is regarded as superior to the outcome with unchanged policy, shown in Table 3, depends upon the weights assigned to the unemployment and inflation objectives. 


\begin{tabular}{|c|c|c|c|c|c|c|c|}
\hline \multicolumn{2}{|c|}{$\begin{array}{l}\text { Compensation per } \\
\text { manhour }\end{array}$} & \multicolumn{2}{|c|}{$\begin{array}{c}\text { Consumption price } \\
\text { deflator }\end{array}$} & \multirow[b]{2}{*}{$\begin{array}{c}\text { Exports } \\
\text { (billions } \\
\text { of } \\
\text { current } \\
\text { dollars) }\end{array}$} & \multirow[b]{2}{*}{$\begin{array}{l}\text { Imports } \\
\text { (billions } \\
\quad \text { of } \\
\text { current } \\
\text { dollars) }\end{array}$} & \multirow{2}{*}{$\begin{array}{c}\text { Corporate } \\
\text { profits } \\
\text { (billions } \\
\text { of } \\
\text { current } \\
\text { dollars) }\end{array}$} & \multirow{2}{*}{$\begin{array}{c}\text { Value of } \\
\text { corporate } \\
\text { shares } \\
\text { (billions } \\
\text { of } \\
\text { current } \\
\text { dollars) }\end{array}$} \\
\hline $\begin{array}{l}\text { Amount } \\
\text { (cents) }\end{array}$ & $\begin{array}{l}\text { Annual } \\
\text { rate of } \\
\text { change } \\
\text { (percent) }\end{array}$ & $\begin{array}{c}\text { Index } \\
(1958= \\
100)\end{array}$ & $\begin{array}{l}\text { Annual } \\
\text { rate of } \\
\text { change } \\
\text { (percent) }\end{array}$ & & & & \\
\hline-0.3 & -0.3 & 1.4 & 4.3 & 0.3 & 3.4 & 1.3 & 16.8 \\
\hline-0.2 & 0.2 & 2.5 & 3.3 & 0.4 & 6.6 & -0.8 & 6.3 \\
\hline 0.4 & 0.5 & 3.4 & 2.7 & 0.4 & 9.2 & -3.7 & -2.3 \\
\hline 1.4 & 1.0 & 3.7 & 0.8 & 0.6 & 8.9 & -7.1 & -3.8 \\
\hline 2.2 & 0.8 & 4.0 & 0.6 & 0.7 & 8.6 & -8.0 & -8.6 \\
\hline 3.0 & 0.7 & 4.2 & 0.7 & 0.8 & 8.4 & -10.0 & -5.5 \\
\hline 3.8 & 0.6 & 4.6 & 0.8 & 1.0 & 8.3 & -10.4 & 5.4 \\
\hline 4.4 & 0.6 & 4.8 & 0.8 & 1.0 & 8.4 & -9.8 & 17.1 \\
\hline 6.9 & 0.3 & 6.1 & 0.7 & 1.8 & 9.1 & 3.0 & 123.3 \\
\hline 6.8 & -0.5 & 7.0 & -0.2 & 2.8 & 8.8 & 4.7 & 83.2 \\
\hline
\end{tabular}

Accommodative monetary policy has no single definition. The definition that we chose is one that sometimes has been advanced as a reasonable response to an exogenous price shock. Other definitions would lead to different results involving, among other things, different amounts of unemployment and inflation. However, since the increase in oil prices has several kinds of impact on the economy, no monetary policy is capable of offsetting all its effects.

\section{Wage and Price Controls}

We conclude with an examination of the recent wage-price controls and some observations on what might be expected from their removal. ${ }^{22}$ The impact of the controls was estimated by comparing two simulations of the full system holding fiscal and monetary policy unchanged in the

22. Robert Gordon has recently provided an analysis of the controls using only a wage-price sector. His analysis is approximately equivalent to assuming that policy was so adjusted that the controls had no effect on the unemployment rate. See Gordon, "Response of Wages and Prices." 
Table 9. Simulated Economic Impact of the Increase in Oil Prices with Accommodating Monetary Policy, by Selected Quarters

Deviation from control simulation

\begin{tabular}{|c|c|c|c|c|c|c|}
\hline \multirow{2}{*}{$\begin{array}{c}\text { Quarter } \\
\text { of } \\
\text { simu- } \\
\text { lation }\end{array}$} & \multicolumn{2}{|c|}{ Gross national product } & \multirow{2}{*}{$\begin{array}{c}\text { Consump- } \\
\text { tion ex- } \\
\text { penditures } \\
\text { (billions } \\
\text { of } 1958 \\
\text { dollars) }\end{array}$} & \multirow{2}{*}{$\begin{array}{c}\text { Disposable } \\
\text { income } \\
\text { (billions } \\
\text { of } 1958 \\
\text { dollars) }\end{array}$} & \multirow{2}{*}{$\begin{array}{l}\text { Unem- } \\
\text { ploy- } \\
\text { ment } \\
\text { rate } \\
\text { (per- } \\
\text { cent })\end{array}$} & \multirow[b]{2}{*}{$\begin{array}{l}\text { Treasury } \\
\text { bill rate } \\
\text { (percent }\end{array}$} \\
\hline & $\begin{array}{l}\text { Billions } \\
\text { of current } \\
\text { dollars }\end{array}$ & $\begin{array}{l}\text { Billions } \\
\text { of } 1958 \\
\text { dollars }\end{array}$ & & & & \\
\hline 1 & 0.4 & -2.1 & -2.6 & -5.4 & 0.1 & -0.2 \\
\hline 2 & -1.9 & -5.0 & -4.8 & -9.7 & 0.3 & -0.4 \\
\hline 3 & -4.2 & -7.7 & -7.3 & -13.7 & 0.5 & -0.6 \\
\hline 4 & -5.3 & -9.6 & -8.7 & -14.9 & 0.6 & -0.5 \\
\hline 5 & -6.1 & -11.2 & -10.2 & -16.2 & 0.8 & -0.5 \\
\hline 6 & -7.0 & -12.7 & -11.6 & -17.4 & 0.9 & -0.6 \\
\hline 7 & -7.4 & -13.6 & -12.6 & -18.3 & 1.0 & -0.5 \\
\hline 8 & -6.7 & -13.5 & -13.2 & -19.1 & 1.1 & -0.5 \\
\hline 12 & 10.4 & -1.9 & -10.8 & -17.6 & 0.6 & 0.1 \\
\hline 16 & 9.3 & -3.8 & -12.4 & -18.6 & 0.8 & 0.1 \\
\hline 20 & 8.9 & -3.7 & -10.9 & -19.0 & 0.8 & 0.0 \\
\hline 24 & -2.1 & -10.3 & -13.7 & -22.1 & 1.0 & -0.2 \\
\hline 28 & -26.8 & -20.2 & -19.1 & -27.7 & 1.6 & -1.4 \\
\hline
\end{tabular}

Source: Simulations covering the $1967-73$ period. It is assumed that the money stock is increased to accommodate the transactions demand of the original price increases. The increase in oil prices is the same as that assumed in Table 3 .

same manner as in the experiment reported in Table 3. In the first simulation, the residuals of the price equation for the period of price controls were added to the price equation; in the second they were not. The rationale for this procedure is the negligible character of the residuals of the price equation prior to the introduction of the controls, revealed in Figure 2, so that we assume that the errors thereafter are due entirely to controls. Under this assumption, the difference between the two simulations measures the effects of the controls in the full system. These are summarized in Table 10.

Over the whole interval through the end of 1973, the price controls raised real output by an estimated cumulative total of $\$ 17$ billion over what it would have been in their absence. The price of consumption goods $\left(P_{c o n}\right)$ ends up 3.8 points $(2.5$ percent) higher without the controls, after being as much as 5.1 points ( 3.7 percent) higher at a time coinciding with the end of Phase II. By the end of the period, prices are rising some- 


\begin{tabular}{|c|c|c|c|c|c|c|c|}
\hline \multicolumn{2}{|c|}{$\begin{array}{l}\text { Compensation per } \\
\text { manhour }\end{array}$} & \multicolumn{2}{|c|}{$\begin{array}{c}\text { Consumption price } \\
\text { deflator }\end{array}$} & \multirow[b]{2}{*}{$\begin{array}{c}\text { Exports } \\
\text { (billions } \\
\text { of } \\
\text { current } \\
\text { dollars) }\end{array}$} & \multirow[b]{2}{*}{$\begin{array}{c}\text { Imports } \\
\text { (billions } \\
\text { of } \\
\text { current } \\
\text { dollars) }\end{array}$} & \multirow{2}{*}{$\begin{array}{c}\text { Corporate } \\
\text { profits } \\
\text { (billions } \\
\text { of } \\
\text { current } \\
\text { dollars) }\end{array}$} & \multirow{2}{*}{$\begin{array}{l}\text { Value of } \\
\text { corporate } \\
\text { shares } \\
\text { (billions } \\
\text { of } \\
\text { current } \\
\text { dollars) }\end{array}$} \\
\hline $\begin{array}{l}\text { Amount } \\
\text { (cents) }\end{array}$ & $\begin{array}{l}\text { Annual } \\
\text { rate of } \\
\text { change } \\
\text { (percent) }\end{array}$ & $\begin{array}{c}\text { Index } \\
(1958= \\
100)\end{array}$ & $\begin{array}{l}\text { Annual } \\
\text { rate of } \\
\text { change } \\
\text { (percent) }\end{array}$ & & & & \\
\hline-0.3 & -0.3 & 1.2 & 4.1 & 0.2 & 2.7 & 1.4 & 21.7 \\
\hline-0.2 & 0.0 & 2.0 & 3.0 & 0.3 & 5.3 & 0.7 & 29.2 \\
\hline 0.0 & 0.3 & 2.8 & 2.5 & 0.3 & 7.6 & -0.1 & 28.4 \\
\hline 0.5 & 0.6 & 3.0 & 0.7 & 0.4 & 7.3 & -0.6 & 27.1 \\
\hline 0.8 & 0.4 & 3.2 & 0.5 & 0.5 & 7.2 & -0.6 & 31.0 \\
\hline 1.0 & 0.2 & 3.4 & 0.3 & 0.6 & 7.1 & -0.5 & 48.0 \\
\hline 1.1 & 0.1 & 3.5 & 0.2 & 0.6 & 7.2 & 0.0 & 64.2 \\
\hline 1.0 & -0.1 & 3.5 & 0.1 & 0.6 & 7.4 & 1.3 & 97.9 \\
\hline 1.8 & 0.3 & 4.1 & 0.4 & 0.9 & 9.9 & 11.5 & 160.6 \\
\hline 2.9 & 0.0 & 4.4 & -0.3 & 1.1 & 10.5 & 9.7 & 140.4 \\
\hline 2.3 & -0.2 & 4.4 & 0.0 & 1.0 & 11.2 & 10.6 & 177.0 \\
\hline 0.6 & -0.6 & 4.2 & -0.4 & 0.9 & 10.6 & 6.1 & 148.3 \\
\hline-4.8 & -1.3 & 3.0 & -1.2 & 0.4 & 7.9 & 6.1 & 108.5 \\
\hline
\end{tabular}

what less in the simulation without price controls. This observation may be misleading, since in the last four quarters of the simulations, the economy moves from the restrictive Phase II to the less restrictive Phases III and IV.

The behavior of compensation per manhour may give a better idea of the difference between the ending rates of inflation. By the end of the period, the rate of wage increase is the same with or without the controls. In their absence, higher prices would have driven up interest rates for a given money stock, which in turn would have lowered output and employment and eventually slowed inflation. This depressing effect is partially offset, however, by the higher level of corporate profits and stock prices in the no-controls simulation, which stimulates consumption and investment demand. The difference is greatest in the last quarter of 1972, when corporate profits are $\$ 20$ billion higher without the controls and the value 


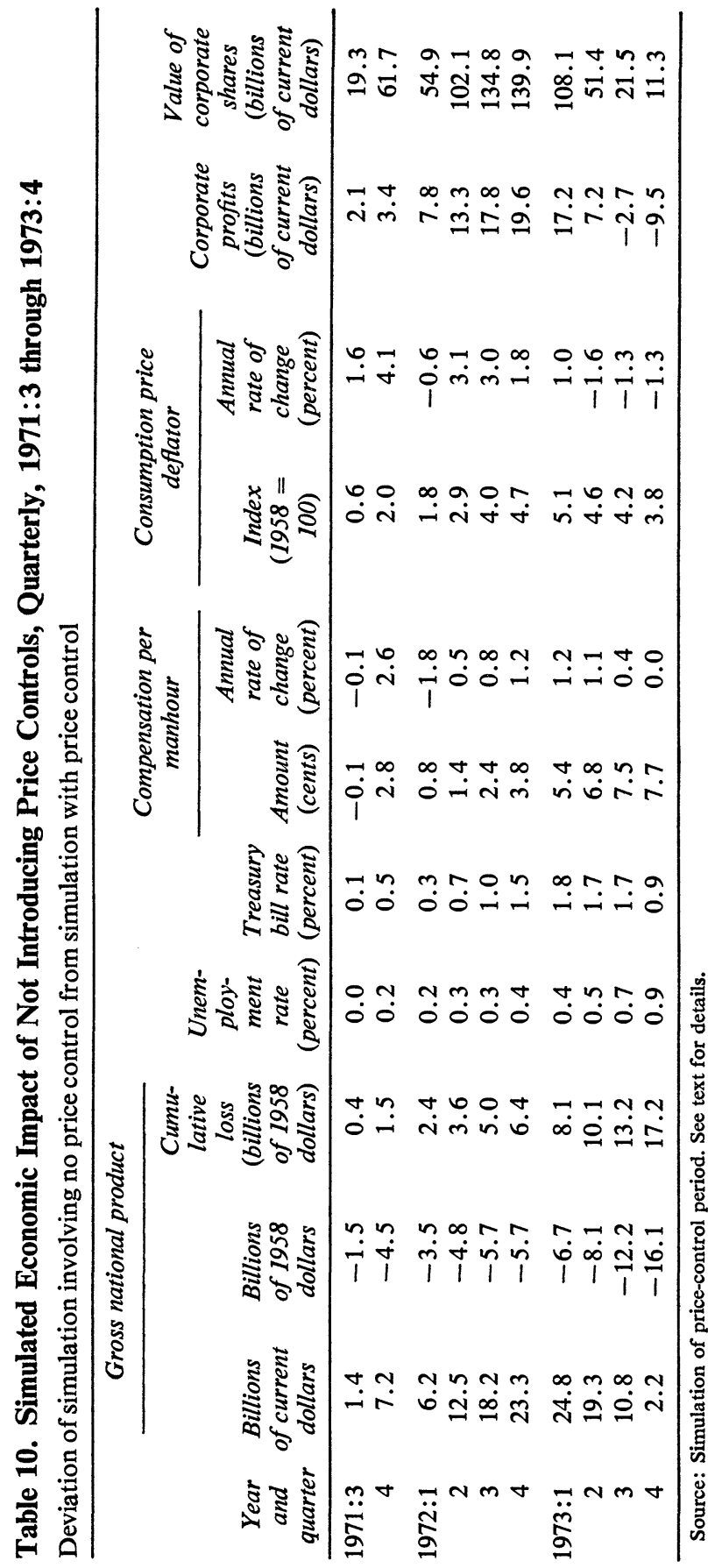


of common stocks is $\$ 140$ billion higher. Near the end of the simulation the depressing effects of the high level of prices, acting through interest rates, become the predominant factor. Given our assumption of no change in the money stock between simulations, high inflation in the early part of the no-control simulation must be offset by low inflation later. This adjustment will require a period of higher unemployment rates, which are observed throughout the simulation period and which reach a level that is 0.9 point higher by the end of 1973 . Given the growth in the money stock, the process in which unemployment rises and eventually slows inflation takes much longer in the present case than it does in the case of higher prices for imported oil. The reason is that inflationary disturbances that are purely domestic redistribute income within the economy between profits and personal incomes; while a rise in prices of imported oil reduces real national income and wealth, which immediately helps set in motion the deflationary forces that raise unemployment.

This exercise may overstate the price effects of the controls. First, with controls, the prices at which transactions took place may have exceeded recorded prices because they reflected the elimination of discounts and deterioration of quality. If this phenomenon is important, the residuals in the price equation, which we interpreted as the direct effect of the controls on the price level, are smaller than they appear. Further, it is not reasonable to expect a change in the inflation rate brought about by an administrative squeeze on profits to be repeated or even maintained. If that is how the controls were working, participants in wage bargaining might not have extrapolated the effect in the manner suggested by the price term in the wage equation. The simulation may therefore overstate the indirect downward pressure on wage increases that derived from controls on prices.

However, there is a counter-argument. We have ignored the possible influence of the unusual increases in import prices in the price-control period. These increases may have driven up the prices of import-competing goods. Our price equation does not capture this effect; had there not been controls the increase in import prices might have produced even higher prices than those predicted in the no-controls simulation. To the extent this is true we have understated the effects of the controls.

All in all, the exercise strongly suggests that the controls considerably improved the inflation-unemployment tradeoff while they were operative, particularly during Phase II. Whether the controls were a good idea is 
quite another matter. They have obviously caused some unwanted distortions and if they had been continued without modification, the distortions would have been likely to grow worse. In addition, the total removal of controls in 1974 poses new inflationary problems.

The results of the various simulation experiments strongly suggest that the economy will respond differently to the decontrolling of domestic prices than it will to the increased price of domestic oil. Put most simply, the initial reduction in aggregate demand should be smaller and the upward pressure on prices greater for a price rise coming from decontrol than for a rise of the same size coming from the increase in oil prices. In 1974, policy must cope somehow with the effects of both these shocks at once. 


\section{Comments and Discussion}

David I. Fand: Pierce and Enzler analyze how external shocks may impart inflationary spurts to the economy. One problem is to distinguish the effects on relative prices-high prices-from the effects on the inflation rate-rising prices. If there were no lags, so that these external shocks had immediate effects on the economy, they could be ranked in terms of their potential contribution to inflation: a once-and-for-all change in the relative price of a commodity causes high prices and should theoretically have the least impact on the inflation rate; while an external shock that causes price acceleration should have the greatest inflationary impact. Because of the interactions and the lags, however, a one-shot increase in relative prices may, in fact, affect the rate of inflation over a fairly long period. There is also a second difficulty. Depending on the circumstances, the shocks considered in this paper may incorporate different combinations of these effects: thus when a cartel raises the price of oil, the move may constitute either a one-shot jump or the first in a continuing series of rises; and the imposition of wage and price controls may be either a one-time influence or a continuing factor affecting all prices.

Pierce and Enzler introduce a money demand function that is designed to pick up any increase in money demand resulting from a rise in transactions associated with the higher import prices. Since import prices have risen by as much as 10 percent in recent quarters, the demand for nominal money should have increased significantly. While the PierceEnzler money demand formulation stresses the rise in transactions, the point they are making about the greater demand for nominal money is very similar to a view expressed recently that 6 percent money growth when the inflation rate is 8 percent constitutes a destruction in real balances of approximately 2 percent and is deflationary. Thus while a policy of 6 percent money growth is seen as liberal with, say, a 2 percent inflation 
rate, it is viewed as deflationary in an economy with an 8 percent inflation rate. Since Pierce and Enzler frame their money demand analysis in terms of transactions, they argue that a rise in the price of imports increases transactions and requires an accommodating increase in nominal money. I believe that this change in money demand may be viewed either as a sort of real-balance effect or as a transactions effect.

The results obtained by Pierce and Enzler for the cartelization of oil imports and for wage and price controls may appear surprising. In fact, considering the results of the imposition of an oil cartel shown in their Table 3, it is not clear whether one is viewing the effects of inflation or deflation. Inflation accelerates so sharply in the early periods that the subsequent periods are dominated by deflationary after-effects. The actual deflation scenario in the twenty-eight-quarter simulations shown in the tables varies with the particular assumptions introduced in each simulation. One would imagine that if an oil cartel raises prices and generates one set of macrodynamics, the lowering of prices through wage and price controls should generate the opposite kind of effects. But the wage and price controls simulation in Table 10 is not quite the inverse of the oil cartel case. The differences reflect interest rate effects related to the PierceEnzler money demand function, the different orders of magnitude of the two shocks, and the impact on profits and their distribution in the two cases. A comparison of these simulation results suggests that they are sensitive to the assumptions made in introducing the shocks arising from the oil cartelization and wage-price controls.

Pierce and Enzler question the definition of monetary accommodation, and point out some of the ambiguities in this concept. Given a recognizable and substantial external jolt, like the oil embargo, that could have significant effects on the economy, the monetary authorities are generally expected somehow to accommodate it. But accommodation is very difficult to define in detail for the concrete cases. In one of the simulations monetary accommodation is introduced in the oil cartel case by adding an increment to the growth of money stock in the first quarter equal to the percentage increment in current GNP plus imports arising from the higher oil prices. Obviously, accommodation can be defined in many other ways, depending on one's views about interest rates, prices, unemployment, and inflation.

A related problem is the definition of a constant policy. Pierce and 
Enzler take the 1967-73 rate of monetary growth to represent a constant monetary policy in their simulations. But other alternatives might be interesting. Thus one could try a simulation experiment that embodies relatively unchanged aggregate demand in money terms - that is, $M V$ or unemployment or the rate of inflation. A comparison of these alternative simulation experiments might be useful.

The simulations are all conducted in terms of the growth rates in $\mathbf{M}_{1}$. Since $M_{1}$ diverged from $M_{2}$ several times in the 1967-73 period, the simulation results with an $\mathrm{M}_{2}$ policy would be interesting.

Pierce and Enzler take up the oil cartel and wage-price controls to analyze the cumulative effects on the price level and other macroeconomic variables. They are interested in seeing the impact these jolts have on the inflation rate and what kind of monetary policy may be appropriate to minimize their undesirable repercussions. An alternative procedure is to turn the simulation analysis around-to ask how much of the observed 1973 inflation can be attributed to the domestic policy and how much to external jolts.

The simulations reported in this paper cover the 1967-73 period, when there were essentially no supply shortages and no bottlenecks. As Pierce and Enzler caution, their results may not apply directly to 1973, which suffered from both of these problems. Failure of supply to respond and the impact of the restrained supply on the price level are factors that do not operate ordinarily, and that were not present in the period of the simulation. It is therefore difficult to apply the simulation analysis to the period since 1973, even if the simulation results appear reasonable for a more normal period.

The Pierce-Enzler paper considers how external jolts affect prices and the rate of inflation, and thus illustrates how the external environment can affect movements in the price level of a particular country. If a country is willing to take sufficiently strong domestic measures, it may be able to overcome these external effects, but the required measures may be extreme. The Pierce-Enzler results may therefore be viewed in a larger context as illustrating situations in which a country, in effect, loses control over its price level. The Pierce-Enzler experiments are for the U.S. economythat is, a large country with a relatively small foreign sector; and yet even in this case these external influences may have relatively long-lasting effects on the price level and on the rate of inflation. At the other extreme, 
for a small country with a large foreign sector, it is much easier to imagine a significant impact of the external environment on developments in the domestic price level. Pushing this idea somewhat, it seems to suggest that a country's control over its price level may weaken as its dependence on the outside world deepens.

Perhaps the most interesting and the most important lesson of the Pierce-Enzler simulations is the dramatization of the difficulties in formulating policy to take account of even large and recognizable disturbances. The results obtained with the various simulations depend very much on the particular assumptions used to analyze the external shock and its impact. But even though the kind of inflation and the other macroeconomic consequences associated with a given set of disturbances may be uncertain, the monetary authorities must nevertheless consider alternative accommodating measures and frame policy to keep the economy moving on some acceptable track. This paper does, therefore, point up the dilemma of choosing among policy alternatives with unknown consequences to cope with external disturbances whose effects are also uncertain.

R. J. Gordon: The Pierce-Enzler paper is a very timely and important one. The qualitative results they present are hard to quarrel with. However, I do want to question some of their specific quantitative findings and focus on certain aspects of the model they use which I think could be improved.

Table 3 shows the effects of a one-time increase in the price level without any accommodative response from the Fed-that is, the growth of the money supply remains unchanged. The initial effect is an upsurge of both inflation and unemployment, which seems entirely reasonable. And, since this is a model with a natural unemployment rate, in the long run the economy eventually returns to the unemployment and inflation rates that "would have prevailed had the initial jump in the price level not occurred. The only surprising thing about this eventual outcome is that after seven years, the economy is still not very far along in the long-run adjustment process. At that time the unemployment rate (the last entry in Table 3) is just starting to recede and is still well above its control level.

Another surprise in the results in Table 3 is the reduction in the real wage that occurs. Wages fall 3 percent behind consumer prices with the increase in oil prices and they never catch up. This gap develops because 
the wage equation explains too much of the rate of change of wages in terms of the Phillips curve and too little in terms of past inflation. In this model, high oil prices bring on a recession and high unemployment, which then holds down wages. But I think we have seen a reduction in the effectiveness of high unemployment rates in restraining wages. Increases in welfare benefits and in unemployment compensation have diminished the downward pressure that unemployment used to exert. If I am right, the true story is even more pessimistic than the one told in this paper. Unemployment will take longer to push down wages and prices, and it might not peak out for nine or ten years rather than the six years shown in the model.

But there are conceivable adjustments to the model that would act in the opposite direction, leading to more optimistic results. If the price elasticity for oil is larger than Pierce and Enzler allow, the demand for imported oil will be less than that in their model and the inflationary effects of the oil embargo will be smaller. If one believes the price of imported oil will fall from the $\$ 10$ level they assume, one would have another ground for optimism.

A separate point is the relation between real GNP and unemployment shown in the latter quarters of the simulations in Table 3. Okun's law is clearly violated and there is too much unemployment for the real shortfall in output that is shown. If one believes the output simulation, one can be more hopeful about unemployment than this model is.

Another reason for optimism is brought out by Table 6. Prices may affect wages through the effects that higher product prices have on the demand for labor as well as through the outward shift that higher consumer prices impart to the labor supply curve. This is particularly important if adult males exhibit an inelastic labor supply so that wages depend on the nominal demand for labor. I think this view of the wage relation helps explain why wages have been rising so moderately over the last year.

Table 9, which details the effects of a more accommodating monetary policy, illustrates the magnitudes in the inflation-unemployment tradeoff among which society must choose. Compared with the results in Table 3, the unemployment rate stays about 1 percent lower for five years and the inflation rate is about 1 percent higher at the end of that time. The extra inflation is probably overstated here because of the relative insensitivity 
of wages to more unemployment that I have noted, but the lesson still comes through: only minimal inroads can be made against inflation with even an extended recessionary situation.

\section{General Discussion}

Walter Salant and others questioned the generality of the Pierce-Enzler formulation of the transactions demand for money. Salant suggested that some fraction of exports and imports should be included in a measure of transactions demand. To the extent that the demand is associated with financing production, exports should be included; and to the extent that it is associated with financing final purchases, imports should be included. GNP already includes exports fully and the Pierce-Enzler adjustment incorporates imports fully as well. But unlike goods and services that are produced and sold in the United States, exports and imports do not embody both these aspects of transactions demand. Jared Enzler conceded that Salant had a valid conceptual point, but argued that the exact proportions in which imports and exports should enter transactions demand could not be known, and that the simple procedure of adding all imports was a substantial improvement over ignoring them at a time when import prices were rising abruptly. James Pierce noted that the Federal Reserve is now collecting data on the ownership of demand deposits, which might facilitate analysis of the distribution of money balances between households and business, and hence the nature of transactions demand.

William Nordhaus asserted that the oil embargo would greatly stimulate capital investment since, in most studies, capital and energy are substitutes in production. This upsurge of investment might be a significant offset to deflationary pressures arising from higher oil prices. William Brainard replied that the response of business investment in the aggregate was not so clear; the energy shortage was curtailing expansion plans of some industries, such as utilities. Enzler explained that he and Pierce regarded the immediate response of business investment as too uncertain to permit incorporating any special effects from that source in the model. However, even if investment were stimulated, it could not offset many of the complications arising from the higher oil prices. He noted that the possibility of a substantial induced rise in exports was modeled, and pro- 
vided some evidence on how a surge in demand in other sectors, such as business investment, would alter the main simulation.

Salant noted that a policy to offset the effects of the rise in oil prices on domestic output and employment could not also restore the levels of consumption and investment. Higher oil prices caused a deterioration in the terms of trade that required a reduction in real consumption and investment. John Kareken added that the extent of such an effect would depend on what oil exporters did with their higher revenues. In the basic case of the model, it is assumed that they never expand their demand for U.S. goods so that no need arises to aim at a lower level of domestic consumption and investment.

Nicholas Kaldor offered a more pessimistic view of price developments than that embodied in the model. In view of the British experience, he believed that industrial prices and wages would rise fully to reflect the rise in oil prices, pushing the price level substantially higher than Pierce and Enzler project. Wages would not be restrained significantly by modest increases in unemployment; and, because of the worsening in unemployment that would ensue, the central bank would not try to hold to a growth path for the money supply as Pierce and Enzler had assumed. 